\title{
Virtual reality and gamification in marketing higher education: a review and research agenda
}

\section{Realidad virtual y gamificación en la educación superior de marketing: revisión y agenda futura de investigación}

Virtual reality and gamification

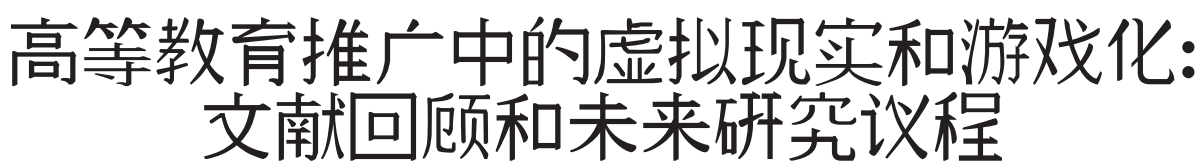

Sandra Maria Correia Loureiro and Ricardo Godinho Bilro Instituto Universitário de Lisboa (ISCTE-IUL) and Business Research Unit (BRU-IUL), Lisboa, Portugal, and

Fernando José de Aires Angelino Instituto Universitário de Lisboa (ISCTE-IUL), Lisboa, Portugal

\begin{abstract}
Purpose - The purpose of this paper is to review studies on the use of virtual reality (VR) and gamification to engage students in higher education for marketing issues to identify the research topics, the research gaps and to prepare a future research agenda.

Design/methodology/approach - A literature review is performed based on two search terms applied to Web of Science, resulting in a final pool of 115 articles. A text-mining approach is used to conduct a full-text analysis of papers related to VR and gamification in higher education. The authors also compare the salient characteristics presented in the articles.

Findings - From this analysis, five major research topics are found and analysed, namely, teaching methodologies and education, experience and motivation, student engagement, applied theories in VR and gamification. Based on this and following the theory concept characteristics methodology framework, the paper provides directions for future research.
\end{abstract}

(C) Sandra Maria Correia Loureiro, Ricardo Godinho Bilro and Fernando José de Aires Angelino. Published in Spanish Journal of Marketing - ESIC. Published by Emerald Publishing Limited. This article is published under the Creative Commons Attribution (CC BY 4.0) licence. Anyone may reproduce, distribute, translate and create derivative works of this article (for both commercial and non-commercial purposes), subject to full attribution to the original publication and authors. The full terms of this licence may be seen at http://creativecommons.org/licences/by/4.0/legalcode

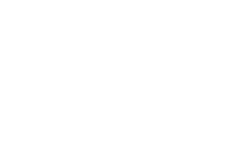


Originality/value - There is no comprehensive review exploring the topics, theories, constructs and methods used in prior studies concerning VR and gamification applied to higher education services based on all the articles published in well-regarded academic journals. This review seeks to provide deeper insights, to help scholars contribute to the development of this research field.

Keywords Virtual reality, Gamification, Education, Learning process, Student engagement, Text-mining

Paper type Literature review

\section{Resumen}

Propósito - En este documento se revisan los estudios sobre el uso de la realidad virtual (RV) y la Gamificación para involucrar a los estudiantes en la educación superior en marketing, se identifican los principales temas de investigación tratados, las lagunas de investigación y se sugiere una agenda futura de investigación.

Diseño/metodología/enfoque - Una revisión de la literatura basada en dos búsquedas en Web of Science (WOS) permitió identificar 115 artículos. La minería de textos se utilizó para realizar un análisis de texto completo de los artículos relacionados con RV y gamificación en la educación superior. Los autores también compararon las características más destacadas de los artículos.

Hallazgos - A partir de este análisis, se encuentran y analizan cinco grandes temas de investigación: metodologías de enseñanza y educación, experiencia y motivación, compromiso de los estudiantes, aplicadas a la RV y la gamificación. Basándose en esto y siguiendo el marco del TCCM, el artículo proporciona una agenda futura de investigación.

Originalidad/valor - No hay una revisión exhaustiva que explore los temas, las teorías, construcciones y métodos utilizados en estudios anteriores relativos a RV y gamificación aplicados a servicios de educación superior basados en todos los artículos publicados en revistas académicas. Esta revisión proporciona una panorámica más detallada y sugiere a los académicos nuevas líneas de trabajo para seguir desarrollando este campo de investigación.

Palabras clave - Realidad virtual, Gamificación, Educación, Proceso de aprendizaje, Participación de los estudiantes, Minería de textos

Tipo de artículo - Revisión de la Literatura

\section{摘要}

目的 - 本文的目的是回顾为了提高学生参与高等教育而使用虚拟现实(VR)和游戏化的营销方面的䂰 究, 以确定它们的研究主题, 㸴究差距, 并以此准备未来的㸴究议程。

文章设计/方法 - 本文的文献综述是基于Web of Science的两个搜索词进行的, 最终搜索出115篇文 章。本文采用文本挖掘方法, 对与高等教育中的虚拟现实和游戏化相关的论文进行全文分析。作者 还比较了这些文章中呈现的显著特征。

㸴究结果 - 从这一调查中, 我们发现并分析了五大㸴究主题, 即教学方法与教育、体验与动机、学 生参与、虚拟现实应用理论和游戏化。在此基础上, 遵循理论概念、特征、方法论框架, 为今后的 研究提供了方向。

本文独创性/价值 - 目前, 在权威学术期刊上发表的所有文章, 都没有对以往关于虚拟现实和游戏 化应用于高等教育服务的㸴究的主题、理论、结构和方法进行全面的综述。本文旨在提供更深刻的 见解, 以帮助学者们为这一研究领域的发展做出贡献。

关键词 - 虚拟现实, 游戏化, 教育, 学习过程, 学生参与, 文本挖掘

\section{Introduction}

Technology is in continuous development, gaining increased relevance in several areas. Distinct stakeholders are willing to engage with organisations and recent technological advancements allow new ways to do so. In services, and specifically in higher education environments, these cases are even more pronounced as organisations are dealing with stakeholders with specific characteristics, such as students. Students are mainly from younger generations, such as 
Millennials or Generation Z, who are digital natives (Mulvey et al., 2019). Virtual reality (VR) is a computer-generated simulation of a situation that allows individuals to be immersed and abstracted from the real environment when interacting with the virtual environment in a manner that appears to be real (Flavián et al., 2019a; Loureiro et al., 2019c; Loureiro et al., 2020). VR can make it easier for students to be more focussed and immersed in the simulation of a task that can be learned and repeated (with or without mistakes) until it is performed in a real environment without mistakes (Bower et al., 2017). At the same time, the use of gamification (game-design elements in non-game contexts to improve the user's engagement) in education seems to emerge and gamification as a tool to motivate and captivate students to learn (Looyestyn et al., 2017; Nurul and Mohamad, 2018; Lopez Carrillo et al., 2019). Therefore, it became relevant for organisations to understand this phenomenon in the scope of marketing and services. In the field of education, there is still no study reviewing the current state-of-the-art on VR and gamification that can show the main research pathways already addressed, present the most important topics and studies, as well as future research avenues. This review gains interest at a time when a large number of universities, colleges and other institutions are converting to distance learning due to restrictive crowding measures (coronavirus disease-COVID-19).

The current study conducts a literature review based on research published in periodicals indexed to Web of Science (WOS). Two distinct search terms are applied to this database, returning a final group of 115 papers. To analyse the content of these papers, the current study resorts to a text mining technique called topic modelling to find latent topics on VR and gamification in higher education. Recently, topic modelling has been used to uncover correlated discussions in text (Loureiro et al., 2019c; Loureiro et al., 2020). The TCCM framework used in prior reviews (Terjesen et al., 2013; Paul and Rosado-Serrano, 2019), in which T stands for theory, C for context, C for characteristics and $\mathrm{M}$ for methodology, is followed to present the future research agenda. As in the case of the review by Paul et al. (2017), this study adapts the framework to consider three components, namely, theory, characteristics and methodology. Consequently, the paper:

- provides an overview of the conceptualisation of the core concept of the topic in analysis;

- presents the theories, characteristics and methodologies found in the articles;

- analyses the most important topics and studies emerging from this literature; and

- suggests a future research agenda.

The remainder of this article is structured as follows: In Section 2, we discuss the review methodology, followed by the data analysis, describing the review, content analysis and clustering and the latent topics emerging from the review in Section 3. Section 4 presents directions for future research and in Section 5, the conclusions, limitations and implications are reported.

\section{Review methodology}

Systematic review papers can be of several types, namely, a structured review focussing on widely used methods, theories and constructs (Canabal and White, 2008; Kahiya, 2018), a framework-based review (Paul and Benito, 2018), a hybrid-narrative with a framework for setting a future research agenda (Bilro and Loureiro, 2020; Paul et al., 2017), a theory-based review (Gilal et al., 2019; Paul and Rosado-Serrano, 2019), a meta-analysis review (Knoll and Matthes, 2017), a bibliometric review (Randhawa et al., 2016) and a review aiming for model/framework development (Paul and Mas, 
SJME

25,2

182

2019). For this paper, the authors adopt a hybrid review, comprising a structured review followed by a TCCM framework.

Following the six Ws of the literature review method (Callahan, 2014) and the wellestablished guidelines for a search method for review articles found in previous reviews (Canabal and White, 2008; Tranfield et al., 2003) an extensive search was conducted on WOS. The assessment of research based on the journal in which it is published is a widely adopted practice (Chavarro et al., 2018; Loureiro et al., 2019c). WOS is a renowned electronic database, the content of the WOS collections is selective and consistent and an independent and detailed editorial process ensures journal quality (Clarivate, 2019). The research process was undertaken by a research team comprising all the authors of the present paper, who looked for all publications in scholarly journals published until the end of 2019 in the WOS database. To locate the most relevant studies addressing the purpose of this review, the researchers made two queries using the keywords "VR" and "gamification". The use of these two keywords is central to the focus of our research. The reason for deciding to use both keywords was based on the prevalence of the terms in the existing literature. For these two sets of queries, the researchers added the keywords of "education" and the relevant marketing topics, such as "marketing" or "services", which resulted in the search expressions below. The search process was conducted for keywords in the title, abstract and keywords. These keywords were selected based on their relevance to the topic under review. Most of these keywords are followed by a wildcard to account for distinct possibilities from the root word. The final queries for our search are:

Query 1:

$\mathrm{TS}=($ VIRTUAL REALITY* AND EDUCATION*AND (MARKETING OR SERVICE* $*)$

Query 2:

$$
\text { TS }=(\text { GAMIFICATION* AND EDUCATION*AND (MARKETING OR SERVICE*) }
$$

The first results from using these two queries reveal a total of 281 articles for Query 1 and 150 articles for Query 2. These results show relevant information and indicate there is a lack of research on these topics, which highlights the relevance and appropriateness of this paper. The results achieved from the previous two queries were filtered to return only papers in English in peer-review journals, returning 128 articles for Query 1 and 69 articles for Query 2 (Figure 3). We can recognise the range of scientific areas these articles come from, considering their dispersion among the different journals publishing them. This analysis shows that this set of papers (197 in total) are from a varied set of scientific areas, such as not only marketing and educational environments but also computer science and engineering and medicine and health sciences. We can see the distribution of the most frequent WOS categories in Figure 1 for Query 1 and Figure 2 for Query 2.

As shown in Figure 1, with the distribution for Query 1 using the keyword VR, most of the WOS categories are related to computer science, surgery and educational research. On the other hand, when we analyse the distribution from Query 2 (Figure 2), we conclude that most of the WOS categories are related not only to educational research and computer science but also to business and management. These results show there are differences in the research outputs if we are referring to VR or gamification. VR is more present in research on medicine and health 


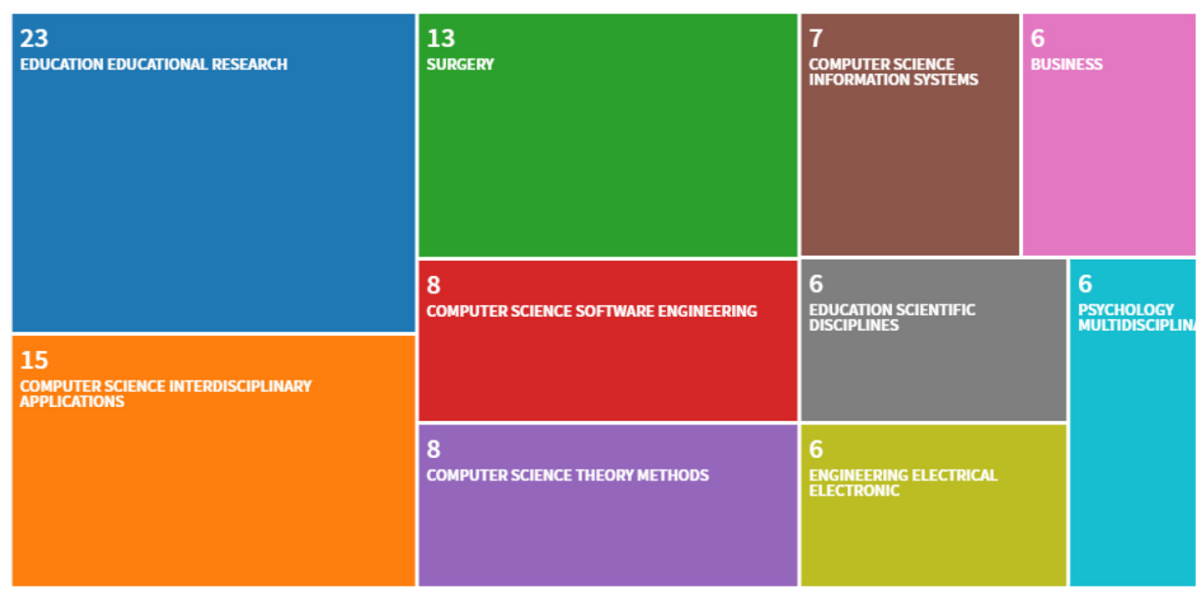

\section{Virtual reality and gamification}

183

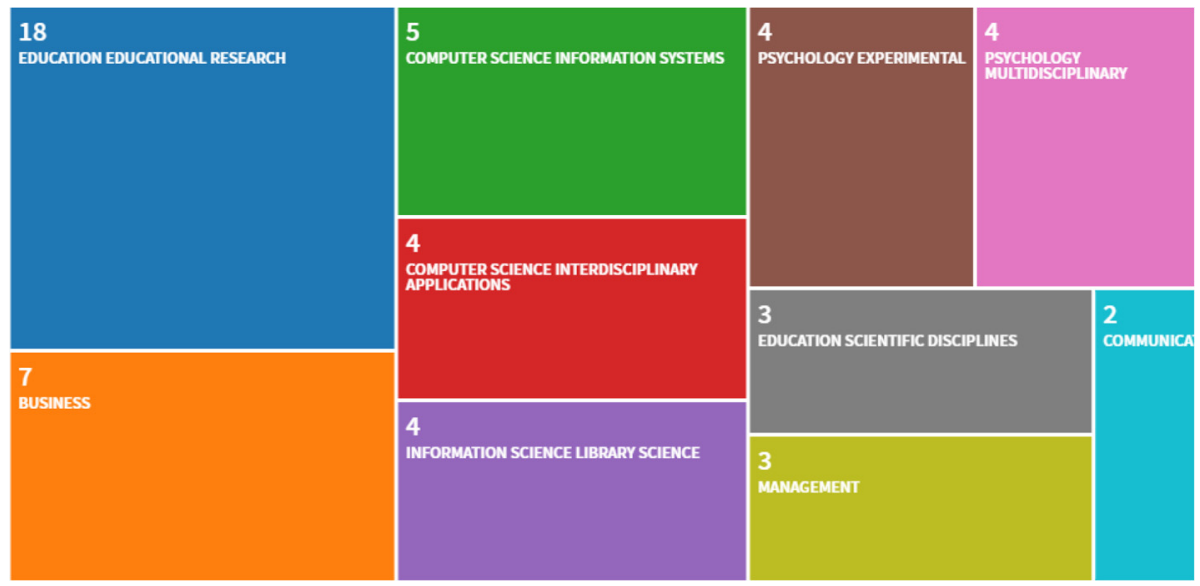

Figure 2.

Distribution of articles per WOS categories: Query 2

sciences, and other scientific areas, while gamification starts to be more widely used in studies on business and management.

Based on the dispersion analysis mentioned in the previous section, the authors resort to content validation of each paper to guarantee that this literature review focusses on our field of research. This content validation was made independently by each of the authors, and by two independent experts in these topics following the quality criteria adapted from Pittaway et al. (2004) and Macpherson and Holt (2007) (see Appendix). The output of this content validation results in our final set of 115 articles - 67 from Query 1 and 48 from Query 2 which are used in this literature review (Figure 3).

\section{Data analysis}

\subsection{Descriptive review}

Analysing this final pool of 115 articles, we find that the first article published in the group of articles resulting from Query 1, related to VR, is from 1999 (Figure 4) and that the majority of articles are from the past five years (2015 onwards). 
SJME

25,2

184

Figure 3.

Procedure flow chart for selecting the final pool of papers
Figure 4.

Reality-virtuality continuum
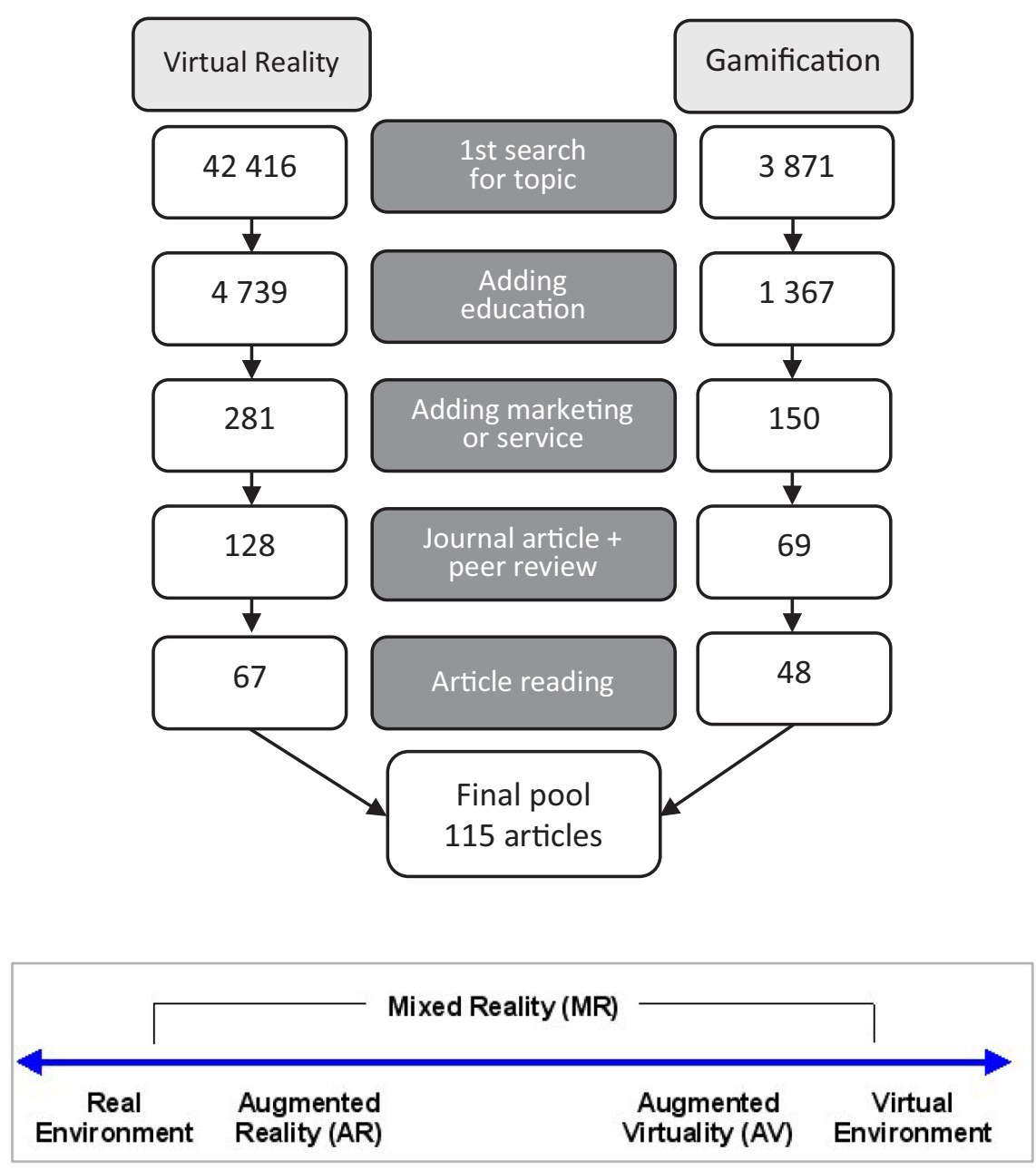

Source: Milgram and Kishino (1994)

These results are quite different from the results achieved from Query 2, using the concept of gamification. As we can see in Figure 4, the first article to be published in this set of articles is from 2014, and most of the articles are from the past three years. We can see some significant differences between the results from VR and gamification. Articles devoted to VR are more common and have appeared since 1999. In contrast, articles on gamification are much more recent as we only find articles from the past five years (from 2014). These results show both topics as being very recent in the literature, with little research devoted to them, highlighting the need for further studies and the relevance of this paper.

Moving forward with this analysis, we underline another relevant issue, which is associated with the journals where the articles of our final pool were published. Once again, the division between both queries shows differences in the publishing of articles and 
research development between VR and gamification. Table 1 shows the journals with most published articles from Query 1, devoted to VR. Overall, some journals devoted to humancomputer interaction, such as Computers and Education or Computers in Human Behaviour have several articles published. Other journals, specifically devoted to the marketing sphere also appear, such as the Journal of Interactive Marketing and Journal of Consumer Research. Nonetheless, most journals still focus on other scientific areas such as computers and technology or medicine. This pool of papers only includes 27 papers out of a total of 67 , meaning that most of the journals have only published one article on this topic.

Analysing the final pool of articles from Query 2 (Table 1), devoted to gamification and the journals with most published articles, we find, once again, some differences as in the previous analysis for Query 1. The journals with most published articles are the Journal of Interactive Marketing and Computers in Human Behaviour. Others, such as the Journal of Marketing Education and International Journal of Engineering Education, also have more than one article published. However, apart from these examples, every other journal only published one article on this topic. It seems relevant to highlight some journals that have published only one article, understand to what extent some journals devoted to business, management and marketing are already publishing research in these domains.

Analysis of Table 1 reveals that the journals publishing most articles (resulting from Query 2) are no longer from computer sciences or medicine but from the interaction between technology and marketing, marketing and interactive environments and education in marketing. These results show a significant difference from the pool of articles resulting from query 1 , as these results are already more devoted to the scientific areas focussed on in this study. Table 2 summarises the theories, characteristics and methodologies used in the articles analysed, following the TCCM framework.

\subsection{Content analysis and clustering}

Content analysis of the final pool of papers (115) is based on a text-mining technique to find the latest topics in the literature review. This type of technique is widely used to reveal

\begin{tabular}{|c|c|c|c|c|}
\hline Query 1 - VR Journal title & $\begin{array}{l}\text { No. of } \\
\text { articles }\end{array}$ & $\begin{array}{l}\text { Query } 2 \text { - gamification Journal } \\
\text { title }\end{array}$ & $\begin{array}{l}\text { No. of } \\
\text { articles }\end{array}$ & \\
\hline Computers and Education & 4 & Journal of Interactive Marketing & 5 & \\
\hline Computers in Human Behaviour & 3 & Computers in Human Behaviour & 4 & \\
\hline $\begin{array}{l}\text { Multimedia Tools and } \\
\text { Applications }\end{array}$ & 3 & Journal of Marketing Education & 2 & \\
\hline $\begin{array}{l}\text { IEEE Transactions on Learning } \\
\text { Technologies }\end{array}$ & 3 & $\begin{array}{l}\text { International Journal of } \\
\text { Engineering Education }\end{array}$ & 2 & \\
\hline Electronic Library & 2 & Teaching and Teacher Education & 1 & \\
\hline Sustainability & 2 & Computers and Education & 1 & \\
\hline $\begin{array}{l}\text { Rural Special Education } \\
\text { Quarterly }\end{array}$ & 2 & $\begin{array}{l}\text { International Journal of } \\
\text { Marketing Communication and } \\
\text { New Media }\end{array}$ & 1 & \\
\hline Journal of Interactive Marketing & 2 & Tourism Management & 1 & \\
\hline Journal of Surgical Education & 2 & $\begin{array}{l}\text { International Journal of Bank } \\
\text { Marketing }\end{array}$ & 1 & \\
\hline$V R$ & 2 & & & \\
\hline Tourism Management & 1 & & & Table 1. \\
\hline Journal of Consumer Research & 1 & & & Journals with most \\
\hline Total & 27 & Total & 18 & published articles \\
\hline
\end{tabular}




\begin{tabular}{l} 
Authors \\
\hline Ma (2019) \\
Tecau et al. (2019) \\
Pappa and Papadopoulos \\
(2019)
\end{tabular}

Wu et al. (2019)

Sun et al. (2019)

Petit et al. (2019)

Cooper et al. (2019)

Fernandez et al. (2019)

Kim and Kim (2018)

Dyer et al. (2018)

Bum et al. (2018)

Suh and Prophet (2018)

Dirin and Laine (2018)

da Silva et al. (2018)

Veselovsky et al. (2018)

Pickering et al. (2018)

Kim et al. (2018)

Yim et al. (2017)

Fombona et al. (2017)

Muñoz-Cristobal et al.

Table 2.

(2017)
S-O-R

Kolb's experiential learning model (do, observe, think, plan) AHP theoretical framework Bowman's theory of interactive task

Theory of embodied cognition

Pre-service teachers' perceptions

Peer to peer network service model

\section{SERVQUAL/ SERVPERF}

Constructivism and connectivism (conceptual maps technique)
Characteritics

Methodology

Attitudes and willingness to help

Experiment

Experience with a disability, attitude barriers, physical barriers and lack of information

Learning experiences

Qualitative approach

Case study

Experience and purchase

Survey

Interactive tasks: navigation, selection/ manipulation and system control. Key factors: navigation modes, operation methods, observation scales and background options

Online experience, engagement, sensory congruency and mental imagery

Engage learning and experience

Learning process

Learning process, progress check, result feedback between instructor and learner in real-time and system for creative English education

Experience and empathy Experience, satisfaction and intent of sustainable participation (engagement) Cognitive and affective reactions and immersive technology

User experience, emotions and engagement

Experience

Online experience and innovative activity

Experience, satisfaction quality (nursing education) and change behaviour

Experience Experience, interactivity, vividness, immersion, usefulness and enjoyment and purchase intention e-Learning and augmented reality

Experiment

Conceptual

Case study

Experiment

Case study

Case study

Survey

Conceptual

Case study

Case study

Case study

Case study

Case study

Mixed

approach

Conceptual

Cooperative/collaborative learning, bricolage mode and learning buckets

Case study and orchestration 


\section{Authors
Bragge et al. (2017)}

Navarro et al. (2017)

Bower et al. (2017)

Pechenkina (2017)

Jung and Dieck (2017)

Durl et al. (2017)

Fokides (2017)

Hoffmann et al. (2017)

He et al. (2017)

Lin and Yang (2016)

Fernandez et al. (2016)

Huang et al. (2016)

Portman et al. (2015)

Yoon, et al. (2015)

Ludlow (2015)

Hartley et al. (2015)

Cho et al. (2015)

Bertram et al. (2015)

Bogacheva and

Voiskounsky (2015)

Avellis et al. (2015a)

Avellis et al. (2015b)

Muñoz-Cristóbal et al.

(2015)

Ali (2015)

Tian et al. (2014)

Billingsley and

Scheuermann (2014)

Anstadt et al. (2013)

Tawfik (2013)

Theory
Dietrich et al. (2017)
six-step framework
TAM

Characteritics

Business simulation, dynamic decision- Survey

making (DDM) in small groups and

culture

Commitment and engagement

Experience, communication and

learning

Experience

Experience, co-creation, word-of-mouth

and visitor intention

Active participation and engagement

Perceived usefulness and perceived ease of use

Experience and engagement

Experience, participation, real-time

bidirectional information exchange,

cave automatic virtual environment

and immersive technology

Experience, e-learning and interactive

games

e-Learning, gamification and VR

simulation

Knowledge sharing and e-learning

Landscape architecture and

environmental planning

Experience, presence, satisfaction and

real-time interaction

VR and virtual environments

Learner participation

Physical presence, social presence,

epistemological belief, situational

interest and perceived achievement

Motivation and perceived value

Experience, avatar-mediated and child

game

Open innovation paradigm

Co-creation, social learning, robotics and VR

Co-creation and e-learning

Experience and orchestration

\section{Satisfaction}

Cultural trauma theory

Experience, physical, emotional, sociocultural and VR

Experience and virtual technology

Experience and virtual world

Experience and virtual technology
Methodology

Virtual reality and gamification

Case study

Case study

Case study

Case study

Survey and

experiment

Survey

Survey

Case study

Case study

Case study

Case study

Conceptual

Mixed

approach

Conceptual

Case study

Survey

Mixed approach

Case study

Experiment

Conceptual

Qualitative approach

Mixed

approach

Survey

Conceptual

Mixed

approach

Case study 


\begin{tabular}{l} 
Authors \\
\hline Maheu et al. (2012) \\
Macfadyen and Dawson \\
(2012) \\
Takács (2011) \\
Alterman et al. (2011)
\end{tabular}

Packman and Meredith (2011)

Cheng and Wang (2011)

Guttentag (2010)

Cheong (2010)

Gustavsson et al. (2009)

Shuhuai et al. (2009)

Katsionis and Virvou

(2008)

Holobar et al. (2008)

Bouras and Tsiatsos

(2006)

Saxena (2006)

Mikropoulos et al. (2003)

Parkinson and Hudson

(2002)

Riva (2000)

Thrush and Bodary

(2000)

Economou et al. (2000)

Vouk et al. (1999)

Martín-Del-Pozo et al. (2019)

Başal and Kaynak (2020)

Robson (2019)

Silva et al. (2019)

Flow theory

Rodrigues et al. (2019)

Göksün and Gürsoy

(2019)

Lopez Carrillo et al.

(2019)

Araujo et al. (2019)

Baydas and Cicek (2019)

Mavroeidi et al. (2019)

\begin{tabular}{|c|c|c|}
\hline \multirow[t]{2}{*}{ Theory } & Characteritics & Methodology \\
\hline & Experience and virtual technology & Case study \\
\hline & Fynerience and telenresence & Case study \\
\hline & Experience and e-learning & $\begin{array}{l}\text { Qualitative } \\
\text { approach }\end{array}$ \\
\hline & Experience and e-learning & $\begin{array}{l}\text { Qualitative } \\
\text { approach }\end{array}$ \\
\hline & Experience and e-learning & Case study \\
\hline & Experience, e-learning and authenticity & Case study \\
\hline & Experience and collaborative learning & Survey \\
\hline & Experience and e-learning & Case study \\
\hline & Experience and virtual environment & Case study \\
\hline & $\begin{array}{l}\text { Experience, e-learning, emotions and } \\
\text { gamification }\end{array}$ & Case study \\
\hline & Experience and e-learning & Case study \\
\hline & Experience and e-learning & Case study \\
\hline & Experience and e-learning & Case study \\
\hline & $\begin{array}{l}\text { Experience, virtual environments, } \\
\text { presence and interaction }\end{array}$ & Survey \\
\hline & $\begin{array}{l}\text { Experience and interactive learning } \\
\text { environments }\end{array}$ & Case study \\
\hline & Experience & Case study \\
\hline & $\begin{array}{l}\text { Experience, military and game } \\
\text { applications }\end{array}$ & Case study \\
\hline & Virtual learning environments & Case study \\
\hline & Quality of service and e-learning & Case study \\
\hline & $\begin{array}{l}\text { Collaborative learning, experience, } \\
\text { attitude and video game }\end{array}$ & Survey \\
\hline & $\begin{array}{l}\text { Motivation and integration of } \\
\text { gamification }\end{array}$ & $\begin{array}{l}\text { Mixed } \\
\text { approach }\end{array}$ \\
\hline & $\begin{array}{l}\text { Gamification, engagement, emotions } \\
\text { and personal brand }\end{array}$ & Experiment \\
\hline \multirow[t]{5}{*}{ Flow theory } & $\begin{array}{l}\text { Gamification, game-based learning, } \\
\text { concentration, clarity, feedback, } \\
\text { challenge, autonomy, social interaction } \\
\text { and perceived learning }\end{array}$ & Survey \\
\hline & $\begin{array}{l}\text { Gamification, computer science and e- } \\
\text { learning }\end{array}$ & Conceptual \\
\hline & $\begin{array}{l}\text { Experience, gamification and } \\
\text { engagement }\end{array}$ & $\begin{array}{l}\text { Mixed } \\
\text { approach }\end{array}$ \\
\hline & $\begin{array}{l}\text { Gamification, motivation and } \\
\text { laboratory practice }\end{array}$ & Experiment \\
\hline & Gamification & Conceptual \\
\hline \multirow[t]{2}{*}{ Churchill paradigm } & $\begin{array}{l}\text { Experience and gamified learning } \\
\text { environment }\end{array}$ & Mixed \\
\hline & $\begin{array}{l}\text { User engagement, gamification and } \\
\text { privacy requirements }\end{array}$ & Conceptual \\
\hline
\end{tabular}

(continued)

Table 2. 


\begin{tabular}{l} 
Authors \\
\hline Hakak et al. (2019) \\
Bayuk and Altobello \\
(2019) \\
De Guimarães et al.
\end{tabular}

(2019)

Dele-Ajayi et al. (2019)

Leclercq et al. (2018)

Equity theory

Canals and Minguell

(2018)

Eppmann et al. (2018)

Nousiainen et al. (2018)

Game-based pedagogy (GBP)

Calderón et al. (2018)

Anouncia and

Kalyanaraman (2018)

Schwade and Schubert

(2018)

Torres-Toukoumidis

et al. (2018)

Lamb et al. (2017)

Kim and Ahn (2017)

SDT

Oleksy and Wnuk (2017) Appraisal theory

Séraphin et al. (2017)

$\mathrm{Su}$ (2017)

Xu et al. (2017)

Çakiroğlu et al. (2017)

Macfarlane and

Tomlinson (2017)

Jurado and Echeverria

Meza (2017)

Gañán et al. (2017)

Durl et al. (2017)
Characteritics

Methodology

Gamification and cloud computing

education

Gamification, financial well-being, app

expertise and perceived benefits

Innovation in teaching, quality in

teaching, organisational commitment

and student retention

Active learning, digital game and

game-based learning

Gamification, engagement, co-creation

and online community

Gamification and learning

Experience and gamification

Gamification, pedagogical,

technological,

collaborative and creative

Motivation, engagement and

meaningful gamification

Gamification and e-learning

Gamification, e-learning and business

simulation game

Gamification and e-learning

Practice-based learning and

improvement, gamification and

experience

Gamification, intrinsic motivation, extrinsic motivation, loyalty, need for autonomy and reward

Satisfaction, social interactions and place attachment

Adaptive learning and gamification

Meaningful gamification, rewarding

interaction, brand awareness and

satisfaction

Gamification, engagement and

achievement

Gamification, engagement,

performativity, marketing,

infantilisation, surveillance,

gamification and opposition

Experience, engagement and

gamification

Experience, engagement and

gamification

Gamification, VR, sensitisation and engagement
Conceptual

Survey

Survey

189

Case study

Mixed

approach

Case study

Mixed

approach

Mixed

approach

Case study

Case study

Case study

Conceptual

Survey

Experiment

Survey

Qualitative approach

Case study

Qualitative

approach

Conceptual

Case study

Case study

Case study

(continued) gamification

Virtual reality and 


\begin{tabular}{|c|c|c|c|}
\hline Authors & Theory & Characteritics & Methodology \\
\hline $\begin{array}{l}\text { Garcia-Fernandez et al. } \\
\text { (2017) }\end{array}$ & & Gamification, motivation and effort & Case study \\
\hline Ketyi (2016) & & $\begin{array}{l}\text { Gamification, effectiveness and user } \\
\text { satisfaction }\end{array}$ & Case study \\
\hline $\begin{array}{l}\text { Garcia Gaitero et al. } \\
\text { (2016) }\end{array}$ & & $\begin{array}{l}\text { Gamification, self-regulation and } \\
\text { motivation }\end{array}$ & Conceptual \\
\hline $\begin{array}{l}\text { Canhoto and Murphy } \\
\text { (2016) }\end{array}$ & & $\begin{array}{l}\text { Gamification and experiential learning } \\
\text { initiative }\end{array}$ & Case study \\
\hline $\begin{array}{l}\text { Gopinath Bharathi et al. } \\
\text { (2016) }\end{array}$ & & $\begin{array}{l}\text { Gamification, user engagement, game } \\
\text { design features, behaviour change and } \\
\text { user engagement }\end{array}$ & Case study \\
\hline Hofacker et al. (2016) & Regulatory fit theory & $\begin{array}{l}\text { Gamification, game design, story, } \\
\text { aesthetics, attitude and engagement }\end{array}$ & Conceptual \\
\hline Fernandez et al. (2016) & & Gamification, VR and experience & Case study \\
\hline Siemens et al. (2015) & & $\begin{array}{l}\text { Gamification, motivation, intrinsic } \\
\text { motivation, brand attitudes, game } \\
\text { effort and enjoyment }\end{array}$ & Experiment \\
\hline Dicheva et al. (2015) & & $\begin{array}{l}\text { Gamification, experience and game } \\
\text { design elements }\end{array}$ & Conceptual \\
\hline $\begin{array}{l}\text { Doumanis and Smith } \\
\text { (2015) }\end{array}$ & $\begin{array}{l}\text { Cognitive theory of } \\
\text { multimedia learning }\end{array}$ & $\begin{array}{l}\text { Gamification, mobile guide } \\
\text { applications, player experience, } \\
\text { cognitive accessibility and usability }\end{array}$ & Case study \\
\hline Kaur and Geetha (2015) & & $\begin{array}{l}\text { Gamification, engagement and self- } \\
\text { learning }\end{array}$ & Case study \\
\hline $\begin{array}{l}\text { Piñeiro-Otero and Costa- } \\
\text { Sánchez (2015) }\end{array}$ & & $\begin{array}{l}\text { Game experience, engagement, } \\
\text { interaction, motivation and } \\
\text { participation and immersive game }\end{array}$ & Case study \\
\hline $\begin{array}{l}\text { Koivisto and Hamari } \\
\text { (2014) }\end{array}$ & $\begin{array}{l}\text { UTAUT theory } \\
\text { (TAM) }\end{array}$ & $\begin{array}{l}\text { Gamification, social, hedonic, utilitarian } \\
\text { benefits, perceived enjoyment and } \\
\text { usefulness and ease of use }\end{array}$ & Survey \\
\hline Harman et al. (2014) & & $\begin{array}{l}\text { Gamification and diffusion of } \\
\text { innovations }\end{array}$ & $\begin{array}{l}\text { Network } \\
\text { analysis }\end{array}$ \\
\hline Kim (2014) & & $\begin{array}{l}\text { Gamification and decision support } \\
\text { model }\end{array}$ & Case study \\
\hline
\end{tabular}

Table 2.

latent topics in scholarly documents (Loureiro et al., 2019c; Loureiro et al., 2020). Helping researchers to implement this technique is text-mining software (MeaningCloud), in which a text clustering technique is performed. This technique allows processing and aggregating a large amount of unstructured text to extract relevant information (Fan et al., 2006), as it can create groups (clusters) by analysing the complete text (Fan et al., 2006; Srivastava and Sahami, 2009). The software tool perceives a text as being in one group of concepts (known as clusters) rather than another, being more similar to each other than to those in other clusters (Spinakis and Chatzimakri, 2005) and then the text-mining system classification for cluster sizes is used to select the suitable number of clusters (Punj and Stewart, 1983). The algorithm receives a set of texts and returns the list of detected clusters. Each cluster is assigned a descriptive name, a size value (indicating its relative importance in relation to all clusters) and the list of elements included in the cluster.

After the cluster analysis is performed using the text-mining software tool, a large variety of clusters emerges. In deciding the relevant number of clusters to use in this review, the researchers stopped accepting new clusters when they were too small (Milligan and Cooper, 1985), which means using a cut-off size value to identify the most appropriate 
cluster size. In this case, it was decided to use a cut-off value $>=300$, meaning that only clusters with a size larger than 300 are accepted. The choice of cut-off value is associated with the number of clusters, this being the size value that allows isolating the 10 largest clusters for each query. Based on this, there are two distinct sets of clusters, one for each query made. The results for both queries were not joined, as the intention is to compare the results from Query 1 (VR) and Query 2 (gamification) and find similarities and differences from this analysis. Table 3 presents the results for both queries.

Starting by analysing the results of the clusters for query 1 (Table 3 ), the main clusters are related to VR and virtual environments, which is an expected result. Analysing the rest of the clusters, the second largest group is related to education and teaching, followed by the user's experience (both as immersive virtual experience and other aspects of experience). Finally, the student engagement cluster emerges, which, combined with the topics mentioned above, warrants further investigation. The same analysis is made for the second query on gamification (Table 3). The results show that the main clusters are related to experience and context analysis, aligned with the results for Query 1. The second group of clusters is related to platforms, applications and game elements, which is also an expected result. Another group of clusters is related to learning environments and teaching methodologies and courses in Marketing, followed by the clusters of student engagement and intrinsic motivations.

Based on this analysis and the set of results, it is possible to identify emerging latent topics. An interconnection of topics is perceived among the clusters from each query, and between the two distinct groups of clusters (Table 3) and the results can be aggregated into five major latent topics which are proposed below and considered for further analysis.

\subsection{Latent topics}

Topic 1. Applied theories in VR. According to Loureiro et al. (2019c), four main theories support studies on VR: self-expansion theory, the theory of planned behaviour (TPB), unified theory of acceptance and use of technology (UTAUT) and stimulus-organismresponse (S-O-R) Theory. The last two theories tend to be used more often (Loureiro et al., 2019c).

\begin{tabular}{lrlr}
\hline Clusters - VR & Score & Clusters - gamification & Score \\
\hline VR & $3,524.43$ & Experience and context analysis & 887.30 \\
Virtual environments & $2,082.39$ & Teaching methodologies & 657.70 \\
Teaching methodologies & $1,929.97$ & Platform to support & 525.80 \\
Education and training program & 833.18 & Mobile applications & 436.74 \\
Immersive virtual experience & 721.46 & Game elements & 382.96 \\
Special education & 693.32 & Learning management system & 375.76 \\
& & (LMS) and learning & \\
Aspects of orchestration and & 507.4 & environments & 364.34 \\
experience & & Perceived benefits & 344.95 \\
Real-world & 497.65 & DBAlcourses in marketing & 340.20 \\
Student engagement & 497.02 & Student engagement & 329.22 \\
Virtual instrument systems in & 341.24 & Intrinsic motivation &
\end{tabular}

Virtual reality and gamification reality and learning environments

Table 3. Cluster analysis 
The first (self-expansion theory) lies in the assumption that consumers desire and can accomplish their goals, and so self-expansion is related to psychological models of selfefficacy, intrinsic motivation, self-actualisation and self-improvement motivation. Hence, the self is created through relationships with close others and these relationship partners can draw out otherwise hidden aspects of the self to create greater wholeness (Aron et al., 1998).

TPB claims that subjective norms, attitudes towards behaviour and perceived behavioural control, together shape a consumer's behavioural intentions and actual behaviours (Ajzen, 1991). Here, subjective norms are the person's beliefs about whether other people approve or disapprove of the behaviour. Attitude means the degree to which a person has a favourable or unfavourable evaluation of the behaviour of interest. Perceived behavioural control refers to a consumer's perception of the ability (ease or difficulty) of performing the behaviour of interest. Finally, behavioural intentions are the motivational factors that influence a given behaviour. A strong behavioural intention may lead to actual behaviour.

UTAUT (Venkatesh et al., 2003) is a unified model of the well-known TAM model suggested by Davis et al. (1989). Technology acceptance model (TAM) comprises the perceived usefulness (the degree to which a consumer believes that using a technological system enhances their performance) and perceived ease-of-use (the degree to which consumers believe that using a technological system implies effort) as two main drivers of attitude and behavioural intentions. UTAUT provides a unified view to explain users' acceptance of new technology and acts as a baseline for new technologies inside organisations (Venkatesh et al., 2003). Afterwards, UTAUT is extended to the consumer use context (Venkatesh et al., 2012), by including hedonic motivation, price value and habit and UTAUT2 emerged.

Mehrabian and Russell (1974) propose the S-O-R framework from the perspective of environmental psychology. Afterwards, S-O-R was introduced in the retail context by Donovan and Rossiter (1982). In retail - both online and offline - the stimulus is operationalised as the atmospheric cues, the organism as consumers' emotional and cognitive states and the response as approach or avoidance behaviours (e.g. intention behaviour, re-patronage or store search). S-O-R has provided the theoretical basis also in $\mathrm{m}$ commerce (Huang, 2017) and emerging technologies including VR (Kim et al., 2018) or the tourism context (Flavián et al., 2019b; Flavián et al., 2020; Loureiro et al., 2014). Environmental stimuli or atmospheric cues or even the stimuli provided by an experience initiate the perceptual, physiological, feeling and thinking activities and cause a change in the consumer's cognitive and emotional state (Roschk et al., 2017; Sherman et al., 1997). The thinking and feeling activities (Organism) intervene in the relationship between the stimulus and the consumer's responses (Roschk et al., 2017).

Topic 2. Applied theories in gamification. Following Kapp (2012, p. 10), "gamification is using game-based mechanics, aesthetics and game thinking to engage people, motivate action, promote learning and solve problems", whereas Zichermann and Cunningham (2011, p.14) consider gamification as "the process of game-thinking and game mechanics to engage users and solve problems". Huotari and Hamari (2012, p. 20) define from a marketing perspective as "a process of enhancing a service with affordances for gameful experiences to support user's overall value creation”. However, the most common definition is provided by Deterding et al. (2011, p.13), as "the use of game design elements in non-game contexts". Hence, gamification is an umbrella term focussing on the use of game elements instead of fully-fledged games to improve user experience and engagement in non-game contexts (Deterding et al., 2011), including education. Gamification has its support in motivational 
theories which include self-determination theory (SDT), self-regulation theory and flow theory.

SDT highlights that an understanding of human motivation requires consideration of innate psychological needs for competence, autonomy and relatedness, leading individuals to have intrinsic and extrinsic motivation to achieve a specific goal. Indeed, individuals are motivated to grow and evolve because of three needs - competence, connection and autonomy. The theory also points out that extrinsic motivators need to be continuous because individuals become addicted to them (Deci and Ryan, 2000).

Self-regulation theory refers to the ability to moderate the thoughts and emotions that govern human behaviour (Leventhal et al., 1984), which one could argue as a sequel to SDT. Indeed, self-regulation has direct associations with motivation (Bandura, 1991), which can be perceived as the motivation to achieve success and is connected to self-discipline and adherence to the strategies that encourage goal achievement.

Finally, the flow theory proposed by Csikszentmihalyi (1990) indicates that flow is an optimal psychological state that individuals experience when engaged in a challenging activity, often resulting in immersion and concentrated focus on a certain task.

Topic 3. Experience and motivation. One of the first authors to claim the importance of experience is Abbott (1955, p.40) saying that "what people really desire are not products but satisfying experiences". In the 1980s, theories emerge in experiential marketing (Hirschman and Holbrook, 1982). Hirschman and Holbrook (1982) study hedonic versus utilitarian consumption, where hedonic consumption represents the multisensory and emotional aspects of consumers' interactions with goods and services, whereas utilitarian consumption is associated with goods and services which are necessary for survival, to fulfil basic needs. However, the roots of customer experience may start in the 1960s when Howard and Jagdish (1969) showed interest of researching the topic.

The 1970s and 1980s are devoted to research focussed on the buying behaviour process, customer satisfaction and service quality. Satisfaction emerges with cognitive and emotional components (Oliver, 1980; Westbrook and Oliver, 1991), followed by the importance of customer delight (Loureiro et al., 2014; Oliver et al., 1997). The effects of satisfaction on loyalty or intention behaviour are extensively confirmed in several studies (Gupta and Zeithaml, 2006).

The 1990s feature models and scales to measure service quality such as SERVQUAL and SERVPERF. In these years, the discussion about the process to measure quality and the best way to use the scales were very prominent (Cronin and Taylor, 1994; Parasuraman et al., 1988), followed by the rise of relationship marketing as a new field in marketing research, focussed on a long-term relationship where both the buyer and seller have an interest in a more satisfying exchange, using the experience to create stronger relationships with customers (Sheth and Parvatiyar, 1995).

The 21st century has seen advanced customer relationship management, paving the way to customer experiences and engagement (Badenes et al., 2019; Brodie et al., 2011; Hollebeek et al., 2014), exploring how organisations can take advantage of customer engagement (Kumar and Pansari, 2016; Rather et al., 2018). Probably, the next steps on this journey will be the development of further studies on the relationship between brands (or non-human mechanisms), humans and devices (Orús et al., 2019), through distinct emerging concepts such as what a brand coolness/device coolness relationship could be (Warren et al., 2019).

The conceptualisation of consumer experience has two major perspectives: experience economy and brand experience. The first perspective is developed by Pine and Gilmore (1998) and considers that experiences occur when firms use services as stages and transform events in memorable experiences. Pine and Gilmore (1998) present the realms of the
Virtual reality and gamification 
experience using two axes. In one axis, there is active or passive participation, whereas education and escapism are on the active side. Education represents the stimulation to learn something new and escapism means immersion in a different time or place. These two facets belong to different parts of the yy axis, that is, education is absorption (being focussed) and escapism is immersion (being completely in a different place) (Billingsley and Scheuermann, 2014; Jung and tom Dieck, 2017; Loureiro et al., 2014). Regarding entertainment, this facet is located in passive and absorption axes suggesting that the activities are fun to watch. Finally, aesthetics (passive and immersion) represents the setting where the experience occurs.

The second perspective, brand experience, was initially proposed by Brakus et al. (2009) and is conceptualised as sensations, feelings, cognitions and behavioural responses evoked by brand-related stimuli that are part of a brand's design and identity, packaging, communications and environments. These authors propose four dimensions for brand experience: sensory, which is related to aesthetics and sensory perceptions; affective, which relies on affect and emotions; behavioural, which is connected with actions when using the brand; and intellectual, which reflects the fact that the brand stimulates curiosity.

Topic 4. Teaching methodologies and education. Teaching means that someone should be interested in learning (Schunk, 2012), so to have the right teaching approach one should also learn about "learning", thus ensuring that learning takes place in the classroom. Therefore, when we observe some of the research by distinct educational psychologists - behaviourist, constructivist and cognitive psychologists - (Agarkar, 2019; Illeris, 2009; Schunk, 2012), several different definitions of learning arise. Based on the definitions presented by Pritchard (2009, p. 2), learning is "a change in behaviour as a result of the experience of practice" and the acquisition of knowledge is "to gain knowledge of or skill in, something through study, teaching, instruction or experience".

One of the biggest challenges faced by lecturers is to be able to capture and retain students' attention, in such a way they can assimilate the teachings and concepts even after they leave the classroom. So, all classroom experiences should be re-evaluated, and new innovative ideas to create a more effective teaching-learning process should be tested and implemented (Kalyani and Rajasekaran, 2018; Kim et al., 2013).

Lecturers can choose from various teaching methodologies and apply those that best suit the needs and circumstances where the teaching-learning process takes place. When choosing teaching methodologies, teachers also need to reflect on how they intend to conduct their classes - a more teacher-centred approach, where teachers are the leading authority or a more student-centred approach, where teachers and students play a similarly active role in the learning process (Lasry et al., 2014; Sesen and Tarhan, 2011).

Some examples of teacher-centred methods of instruction are "flipped classrooms" (O'Flaherty and Phillips, 2015), where students prepare for their in-class assignments at home, watching pre-recorded lessons. Another example is the "direct instruction" method, the more traditional method based on teaching through lectures (O'Flaherty and Phillips, 2015). Regarding student-centred methods of instruction, some examples are "problembased learning" (Jalani and Sern, 2015), where students are asked to solve problems collaboratively. A similar method is "project-based learning", repeatedly confused with the previous method, but with the difference that here it is the student who has to present a problem or question to investigate (Hmelo-Silver, 2004; Jalani and Sern, 2015).

The emergence of new teaching and learning tools and technologies is also a permanent challenge for educators at all levels of education, creating a need for permanent updating on their functioning, usefulness and application in the classroom, which leads to an increase in research on how students learn and respond to different teaching methods (Nilson, 2010). 
This has been the case with gamification (Çakıroğlu et al., 2017; Martí-Parreño et al., 2016; Subhash and Cudney, 2018) and VR (Bhattacharjee et al., 2018; Fernandez, 2017; Janssen et al., 2016; O'Connor and Domingo, 2017), as they are receiving increasing attention and research in the field of education and particularly in higher education, proving to be valid tools both in supporting the teaching-learning process and in arousing increased interest and involvement among students. Several authors, such as Englund et al. (2017) and Kim et al. (2013) claim that the successful use and implementation of some of these educational technologies, as they are mostly dependent on and integrated with various technological supports, means that teachers who want to use them should have some knowledge of how to integrate them into their teaching process.

Technology alone is not enough to change the learning environment. For that to happen, and intense intervention should also occur so that technology follows the teaching and learning strategies, seeking to ensure students' acquisition of knowledge based on digital resources (Marcelo et al., 2015). The use of technology in education also raises several barriers for educators, not only because of the learning curve but also because of the implementation of teaching methods and pedagogical approaches that can generate benefits. Educators need a better understanding of some of the benefits of using technology, especially those that promote greater interest and autonomy among students (Alonso et al., 2019; Sinclair and Aho, 2017).

Topic 5. Student engagement. Stakeholders must become engaged in actively cooperating with organisations to plan, develop, co-create or improve what already exists (Loureiro et al., 2019b). Organisations, whether companies, NGOs or higher education institutions need to know how to stimulate innovation through their stakeholders' engagement (Huggins and Thompson, 2015; Ramaswamy and Ozcan, 2018; Shams and Kaufmann, 2016). The literature has already studied the link between distinct stakeholders' engagement, such as consumers, suppliers, shareholders or students, from different perspectives (Loureiro et al., 2019b; Monferrer et al., 2019).

Researchers have been attempting to understand engagement between firms and distinct stakeholders such as consumers (Bilro et al., 2019; Brodie et al., 2011; Hollebeek et al., 2014; Loureiro et al., 2019a; Pansari and Kumar, 2017; Sprottet al., 2009). Research in this domain is not new, as it has been discussed in areas such as psychology or sociology (Garczynski et al., 2013; Morimoto and Friedland, 2013). Moreover, technological advances have provided people with global communication platforms that promote interaction to exchange information and knowledge (Chen et al.,2010; Dessart et al., 2019). In these online environments, consumers may seek relevant information to make decisions and/or achieve something in their lives (Brandão et al., 2019; Sicilia and Palazón, 2008). So, consumer engagement can be described as a cognitive and affective commitment to an active relationship with the brand as personified by the technology to communicate a specific firm value (Mollen and Wilson, 2010).

Concerning students, a relative consensus emerges in the literature concerning motivation as one of the driving sources for engagement (Ketyi, 2016; Macfarlane and Tomlinson, 2017; Robson, 2019). Motivation can affect students' behaviour or action in a specific environment (Appleton et al., 2008; Skinner et al., 2009). The effect of motivation on students is that the more they are motivated to learn, the more likely it is they will be engaged in learning activities (De Guimarães et al., 2019; Kim et al., 2015). Motivation can be seen as a two-fold concept:

(1) controlled motivation; and

(2) autonomous motivation (Ryan and Deci, 2000b, 2000a).
Virtual reality and gamification 
SJME

25,2

First, controlled motivation appears in student behaviours to respond to external stimuli, such as commenting on peers' discussion board postings to earn a mark for participation (Ryan and Deci, 2000b). In autonomous motivation, student behaviour is consistent with other values and needs (Ryan and Deci, 2000b). Considering these two distinct types of motives, we can see that students with autonomous motivation are more willing to engage in online discussions than students with controlled motivation. Students with autonomous motivation may behave more actively (Xie et al., 2006), maybe more individualistic and collaborative or sustain their actions in cognitive engagement (Xie and Ke, 2011).

Although not consensual in the literature, student engagement can be defined as their psychological investment and behavioural involvement in learning activities (Appleton et al., 2008). Moreover, student engagement is often defined as a multidimensional construct and is usually defined as having three dimensions, namely, behavioural engagement, cognitive engagement and emotional or affective engagement (Fredricks et al., 2004; Jimerson et al., 2003). If we look more deeply into the literature, most research about this topic is found to relate behavioural engagement with students' participation, observation of rules in the classroom and involvement in learning activities (Finn and Voelkl, 1993; Fredricks et al., 2004; Jimerson et al., 2003). Behavioural engagement in online contexts can usually be through discussions or replies to peers. Several authors argue that the number of discussions among peers can be perceived as an indicator of behaviour engagement (Goggins and Xing, 2016). In line with this, research also observed an exciting relationship between discussions among students and achievements (Ramos and Yudko, 2008). Nevertheless, this relationship tends only to exist when discussions are needed.

Concerning emotional engagement, research defined this as students' psychological response to academic environments, such as the feeling of boredom or enjoyment from learning activities (Finn and Zimmer, 2012). It can also be influenced by the relationship with tutors or lecturers and their peers (Fredricks et al., 2004). In the online context, emotional engagement can be linked to students' interests or enjoyment in being part of online conversations and based on social interactions with tutors and colleagues.

Finally, cognitive engagement can be perceived as the idea of expending extra effort to understand multifaceted concepts and/or to master upscaled skills (Finn and Zimmer, 2012; Fredricks et al., 2004). The relevance of this third dimension of cognitive engagement was also perceived and noted in distinct online contexts (Garrison et al., 2000; Putman et al., 2012; Zhu, 2006). Cognitive engagement in online discussions can be stated as the attention and the effort that students spend on interacting through discussions, posts or comments with their peers or tutors (Garrison et al., 2000). It involves the use of multifaceted concepts and/or students' upscale skills, such as analysing, critiquing or reasoning (Putman et al., 2012; Zhu, 2006). Table 4 summarises the five latent topics, key theories and correlated papers.

\section{Directions for future research}

This literature review demonstrates that this field is still rife with many unexplored areas for further study. We divide our recommendations into three distinct, but related aspects, namely, theory, characteristics and methodology. We also suggest research questions that emerge from the literature as a whole and others that come from specific articles analysed.

The question as to how this lack of answers can be rectified comes from novel contributions that continue to be highly valued by this research field, particularly given the fast-paced nature of technological innovation that underpins much of interactive marketing space nowadays. In addition, however, we recommend that research building directly on prior work in a meaningful, relevant and constructive way should also be considered. 


\begin{tabular}{|c|c|c|c|c|}
\hline Topic name & $\begin{array}{l}\text { Key theories and } \\
\text { concepts }\end{array}$ & Topic terms and explanation & Correlated papers & and \\
\hline \multirow[t]{4}{*}{$\begin{array}{l}\text { T1. Foundation } \\
\text { theories in VR }\end{array}$} & $\begin{array}{l}\text { Self-expansion } \\
\text { theory }\end{array}$ & $\begin{array}{l}\text { Self-expansion is related to psychological } \\
\text { models of self-efficacy, intrinsic } \\
\text { motivation, self-actualisation and self- } \\
\text { improvement motivation }\end{array}$ & Aron et al. (1998) & \\
\hline & TPB & $\begin{array}{l}\text { Subjective norms, attitude toward } \\
\text { behaviour and perceived behavioural } \\
\text { control, together shape a consumer's } \\
\text { behavioural intentions and actual } \\
\text { behaviours }\end{array}$ & Ajzen (1991) & 197 \\
\hline & UTAUT & $\begin{array}{l}\text { Unified view to explain user's acceptance } \\
\text { of new technology and acts as a baseline } \\
\text { for new technologies; comprises the } \\
\text { perceived usefulness and perceived ease- } \\
\text { of-use as two main drivers of attitude and } \\
\text { behavioural intentions }\end{array}$ & $\begin{array}{l}\text { Davis et al. (1989); } \\
\text { Venkatesh } \text { et al. } \\
(2003,2012)\end{array}$ & \\
\hline & S-O-R & $\begin{array}{l}\text { The stimulus is operationalised as the } \\
\text { atmospheric cues, the organism as } \\
\text { consumers' emotional and cognitive } \\
\text { states and the response as approach or } \\
\text { avoidance behaviours }\end{array}$ & $\begin{array}{l}\text { Donovan and } \\
\text { Rossiter (1982); } \\
\text { Mehrabian and } \\
\text { Russell (1974) }\end{array}$ & \\
\hline \multirow[t]{3}{*}{$\begin{array}{l}\text { T2. Foundation } \\
\text { theories in } \\
\text { gamification }\end{array}$} & SDT & $\begin{array}{l}\text { Understanding of human motivation } \\
\text { requires consideration of innate } \\
\text { psychological needs for competence, } \\
\text { autonomy and relatedness, leading } \\
\text { individuals to have intrinsic and } \\
\text { extrinsic motivation to achieve a specific } \\
\text { goal }\end{array}$ & Deci and Ryan (2000) & \\
\hline & $\begin{array}{l}\text { Self-regulation } \\
\text { theory }\end{array}$ & $\begin{array}{l}\text { The ability to moderate the thoughts and } \\
\text { emotions that govern human behaviour. } \\
\text { Has direct associations to motivation to } \\
\text { achieve success, self-discipline and } \\
\text { adherence to the strategies that } \\
\text { encourage goal achievement }\end{array}$ & $\begin{array}{l}\text { Bandura, (1991); } \\
\text { Leventhal et al. (1984) }\end{array}$ & \\
\hline & Flow theory & $\begin{array}{l}\text { Flow is an optimal psychological state } \\
\text { that individuals experience when } \\
\text { engaged in an activity that is } \\
\text { challenging, often resulting in immersion } \\
\text { and concentrated focus on a certain task }\end{array}$ & $\begin{array}{l}\text { Csikszentmihalyi } \\
\text { (1990) }\end{array}$ & \\
\hline \multirow[t]{3}{*}{$\begin{array}{l}\text { T3. Experience, } \\
\text { user experience } \\
\text { and motivation }\end{array}$} & $\begin{array}{l}\text { Experience } \\
\text { economy }\end{array}$ & $\begin{array}{l}\text { Experiences occur when firms use } \\
\text { services as stages and transform events } \\
\text { in memorable experiences. Four realms } \\
\text { of experience are presented, namely, } \\
\text { entertainment, educational, aesthetic and } \\
\text { escapism }\end{array}$ & $\begin{array}{l}\text { Pine and Gilmore, } \\
\text { (1998) }\end{array}$ & \\
\hline & Brand experience & $\begin{array}{l}\text { Sensations, feelings, cognitions and } \\
\text { behavioural responses evoked by brand- } \\
\text { related stimuli that are part of a brand's } \\
\text { design and identity, packaging, } \\
\text { communications and environments }\end{array}$ & Brakus et al. (2009) & Table 4. \\
\hline & $\begin{array}{l}\text { Teacher-centred } \\
\text { approach }\end{array}$ & Teachers are the leading authority & (continued) & $\begin{array}{r}\text { Latent topics, key } \\
\text { theories and } \\
\text { correlated papers }\end{array}$ \\
\hline
\end{tabular}




\begin{tabular}{|c|c|c|c|}
\hline Topic name & $\begin{array}{l}\text { Key theories and } \\
\text { concepts }\end{array}$ & Topic terms and explanation & Correlated papers \\
\hline \multirow[t]{5}{*}{$\begin{array}{l}\text { T4. Teaching } \\
\text { methodologies } \\
\text { and education }\end{array}$} & $\begin{array}{l}\text { Student-centred } \\
\text { approach }\end{array}$ & $\begin{array}{l}\text { Teachers and students play a similarly } \\
\text { active role in the learning process }\end{array}$ & $\begin{array}{l}\text { Lasry et al. (2014); } \\
\text { Sesen and Tarhan } \\
\text { (2011) }\end{array}$ \\
\hline & $\begin{array}{l}\text { Flipped } \\
\text { classrooms }\end{array}$ & $\begin{array}{l}\text { Students prepare for their in-class } \\
\text { assignments at home, watching pre- }\end{array}$ & $\begin{array}{l}\text { O'Flaherty and } \\
\text { Phillips (2015) }\end{array}$ \\
\hline & $\begin{array}{l}\text { Direct instruction } \\
\text { method }\end{array}$ & $\begin{array}{l}\text { The more traditional method based on } \\
\text { teaching through lectures }\end{array}$ & \\
\hline & $\begin{array}{l}\text { Problem-based } \\
\text { learning }\end{array}$ & $\begin{array}{l}\text { Where students are asked to solve } \\
\text { problems collaboratively }\end{array}$ & Jalani and Sern (2015) \\
\hline & $\begin{array}{l}\text { Project-based } \\
\text { learning }\end{array}$ & $\begin{array}{l}\text { Where the student has to present a } \\
\text { problem or question to investigate }\end{array}$ & $\begin{array}{l}\text { Hmelo-Silver (2004); } \\
\text { Jalani and Sern (2015) }\end{array}$ \\
\hline \multirow[t]{4}{*}{$\begin{array}{l}\text { T5. Student } \\
\text { engagement }\end{array}$} & $\begin{array}{l}\text { Student } \\
\text { engagement }\end{array}$ & $\begin{array}{l}\text { Students' psychological investment and } \\
\text { behavioural involvement in learning } \\
\text { activities }\end{array}$ & Appleton et al. (2008) \\
\hline & $\begin{array}{l}\text { Behavioural } \\
\text { engagement }\end{array}$ & $\begin{array}{l}\text { Students' participation, observation of } \\
\text { rules in the classroom and involvement } \\
\text { in learning activities }\end{array}$ & $\begin{array}{l}\text { Finn and Voelkl } \\
\text { (1993); Fredricks } \\
\text { et al. (2004); Jimerson } \\
\text { et al. (2003) }\end{array}$ \\
\hline & $\begin{array}{l}\text { Emotional } \\
\text { engagement }\end{array}$ & $\begin{array}{l}\text { Students' psychological response to } \\
\text { academic environments, such as the } \\
\text { feeling of boredom or enjoyment from } \\
\text { learning activities }\end{array}$ & $\begin{array}{l}\text { Finn and Zimmer } \\
\text { (2012); Fredricks } \\
\text { et al. (2004) }\end{array}$ \\
\hline & $\begin{array}{l}\text { Cognitive } \\
\text { engagement }\end{array}$ & $\begin{array}{l}\text { The idea of spending extra effort to } \\
\text { understand multifaceted concepts and/or } \\
\text { to master upscaled skills }\end{array}$ & \\
\hline
\end{tabular}

Table 4.

\subsection{Theory: new research directions}

The majority of the papers analysed (Table 2) tend to be descriptions of practices, cases and examples of applications of VR and gamification for the purpose of learning. Thus, the theories supporting the research analysed tend to be dedicated to the learning process (Cooper et al., 2019; Petit et al., 2019; Sun et al., 2019; Pappa and Papadopoulos, 2019; Doumanis and Smith, 2015). However, we also find theories usually associated with the marketing field, for instance, SERVQUAL/SERVPERF for service quality (Pickering et al., 2018), theories in marketing connected to the adoption of new technologies TAM (Fokides, 2017) or UTAUT (Koivisto and Hamari, 2014). Other theories come from psychology, sociology or biology and are often used in the marketing field, such as appraisal (Oleksy and Wnuk, 2017), self-determination (Kim and Ahn, 2017), S-O-R (Suh and Prophet, 2018) or the flow that is used in the games field (Silva et al., 2019). In this review, we note a deficiency in the use of theories to support each research. Therefore, other theories or the combination of two or more theories used in marketing can be considered in the future, for instance: congruity theory (attitude change towards learning), social identity (modify students' selfidentity or part of their self-concept that derives from the knowledge learned and interpreted) or value-belief-norm (norms are active when students believe that violating them would have adverse effects on what students value). New theoretical lenses that can be specific to this context of using technologies to enhance the learning process in marketing will boost our knowledge. Hence, the following research questions are suggested: 
$R Q 1$. What theories often used in the marketing field could be adapted and combined to give support to studies on the learning process context using VR and gamification?

$R Q 2$. How to develop a specific theory on the learning process context, using VR and gamification?
Virtual reality and gamification

\subsection{Characteristics: new research directions}

A substantial body of research is focussed on concepts and constructs such as experience, engagement, emotions, satisfaction, immersive technologies and gamification (Table 2) (Robson, 2019; Göksün and Gursoy, 2019; Baydas and Cicek, 2019; Cooper et al., 2019; Navarro et al., 2017; Bower et al., 2017). The meaning of these concepts is presented in Sections 4.1 and 4.3. Further research can explore concepts such as co-creation (a joint process of learning among students and/or among lecturers, educators, students and enterprises). The learning process is no longer just an in-person relationship between students and an educator in the classroom. The learning system is evolving to a complex network connecting different actors (e.g. students, lecturers, enterprises, researchers and other stakeholders of higher education institutions) in a community where virtual and real environments are combined. Thus, some research questions arise:

RQ3. How can we build a learning community that allows an integrative educational process? An integrated learning process tends to narrow the gap between educators and students, through creating and implementing new approaches to teaching and learning, using a comprehensive set of teaching tools and methods able to improve students' engagement, motivation and learning outcomes.

RQ4. How to implement an integrated process of learning using gamification and VR, bringing onboard the total cooperation of stakeholders (institutions, educators and students)?

RQ5. How to develop a collaborative system where lecturers and students can create and discuss their experiences from using multimedia lectures and the knowledge benefits gained?

RQ6. What are the best methods to disseminate and encourage educators to explore and learn about new technologies applied to teach?

RQ7. What is the impact of the coopetition settings increasingly used to design cocreation platforms? (Leclercq et al., 2018)

$R Q 8$. What are the strategies that can be used to keep the gamified activity engaging, following a win/lose decision? (Leclercq et al., 2018)

RQ9. Can some dimensions of gameful experiences, such as enjoyment, explain the gameful experience consumers feel when they engage with gamified applications? (Eppmann et al., 2018)

$R Q 10$. Can the perceptions of experience lead to engagement? What might be the mediators between experience and engagement? (Loureiro et al., 2020)

RQ11. Are stakeholders (such as students, consumers or others) more dependent on visualised information (i.e. visual learner) than on text-based information? (Yim et al., 2017) 
SJME

25,2

RQ12. What is the relationship between brands (or non-human mechanisms), humans and devices, through distinct emerging concepts such as what a brand coolness/ device coolness relationship could be? (Warren et al., 2019)

\subsection{Methodology: new research directions}

Case studies, followed by surveys, are the most commonly used methodologies (Table 2). The sample size tends to range between 100 and 300 (Koivisto and Hamari, 2014; Cho et al., 2015; Fokides, 2017; De Guimarães et al., 2019). A small number of studies (10) use a mixed approach, where authors consider the combination of survey/experiment and a qualitative technique (e.g. interviews, focus group and content analysis) (e.g. Anstadt et al., 2013; Ali, 2015; Başal and Kaynak, 2020). The studies using surveys and experiments tend to use structural equations, regression analysis or factorial analysis for data treatment (Fokides, 2017; Silva et al, 2019). Another group of studies is more conceptual, attempting to discuss previous studies, presenting frameworks and suggesting plans to implement learning practices) (Mavroeidi et al, 2019; Torres-Toukoumidis et al, 2018). Living lab experiments are becoming a differentiated methodology in the group of experiments (Avellis et al., 2015a, 2015b; Ma, 2019). Only one study is devoted entirely to network analysis (Harman et al, 2014). Therefore, the challenge is to develop methodologies that can aggregate a community of educational stakeholders, which together can transform the traditional way to teach and learn. The following research questions are proposed:

RQ13. What technological tools and teaching methods could be used simultaneously to promote students' engagement and academic success?

RQ14. Which teaching methods and technologies could be widely tested in higher education institutions to ensure the best learning outcomes?

$R Q 15$. How can $5 \mathrm{G}$ technology contribute to enhancing the learning process using VR and gamification?

$R Q 16$. What is the influence of factors such as screen size, image motion, stereoscopic presentation or a realistic and detailed design on VR experiences? (Loureiro et al., 2019a, 2019b, 2019c)

$R Q 17$. For how long does a mobile augmented reality application succeed in supporting its users' emotional engagement? (Dirin and Laine, 2018)

$R Q 18$. How can the integration of VR into cyber-physical systems and the Internet of Things induce innovative education services in the near future? (Kim et al., 2018)

RQ19. How can the student's interest be enhanced through speech recognition functions, and be used as the educational method to increase experience and engagement? (Kim and Kim, 2018)

RQ20. How do offline and online environments differ in terms of multisensory information processing? How can the optimal personalised multisensory balance be assessed? (Petit et al., 2019)

\section{Conclusions, implications and limitations}

Recent technologies such as VR and gamification are gaining attention in the field of marketing research, and more specifically, in the marketing of services such as education. Through VR and gamification, it is possible to build different teaching scenarios and approaches to be able to 
PUBLICATION YEAR FOR ARTICLES

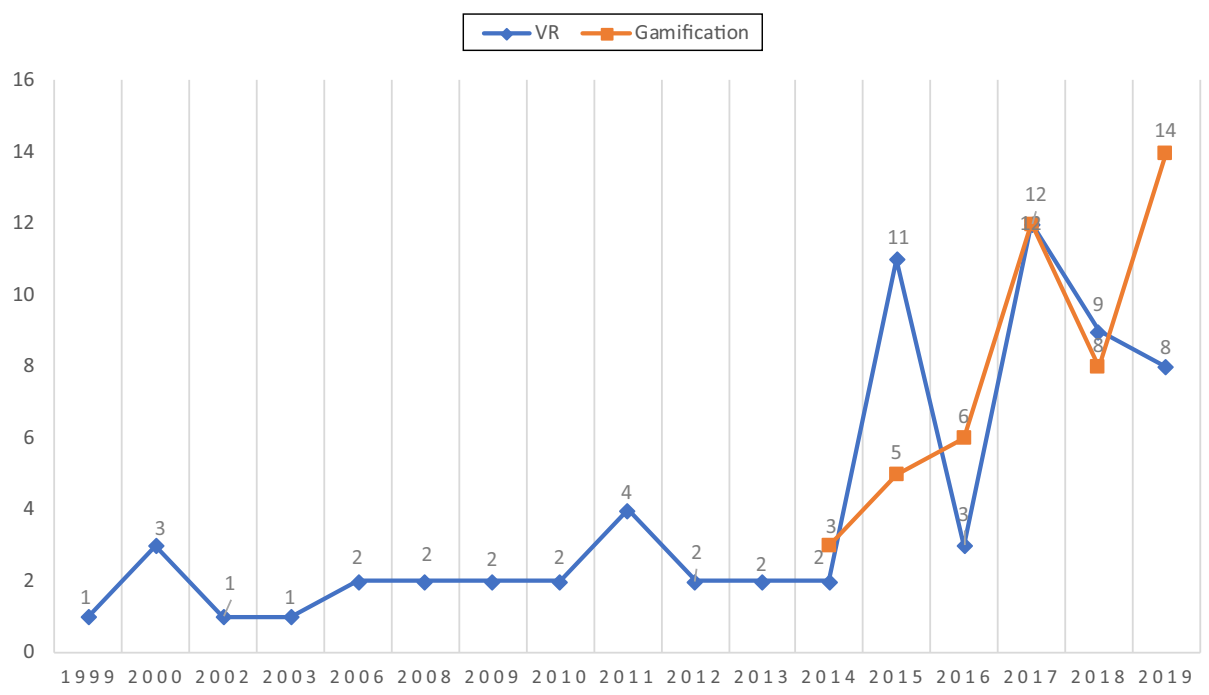

Virtual reality and gamification

201

collect and understand students' reactions, motivation and engagement in their experience with these scenarios and teaching methods. Services in general, and educational methods in particular - especially some of the teaching methods used in higher education- are increasingly subject to the pressure of recent technologies, to supply newer alternatives to support the mission to spread knowledge and to motivate all stakeholders (e.g. students, educators, enterprises). Hence, understanding how to engage students with their subjects may contribute not only to learning strategies but also to services, and society as a whole.

The current research also offers insights for managers. Firstly, managers must perceive gamification and VR in services as having several characteristics linked to users' interactions, as identified in the literature. Managers should be able to understand and design these interactions to achieve the desired results. Secondly, by interacting and participating, users/ participants create levels of engagement. Gamification, specifically, is being used nowadays mainly for educational purposes and market research, with the results of engagement varying amongst studies. The results of this systematic review show that gamification has a positive impact on engagement, especially in the short term. So managers should devote time to determining the effectiveness of gamification in different settings and investigate how gamification can be used to increase long-term engagement with services in general. Thirdly, our research shows that applications with realistic surroundings and which are easy to use by lecturers and students are the basic design requirements for educational VR purposes. Managers should adopt this same strategy either for educational or general service organizations. Fourthly, most articles describe VR applications for knowledge sharing, with a focus on curricula and declarative knowledge. Managers can observe this reality as an opportunity to use VR in a more practice-oriented context, offering opportunities to users/ participants to learn/know by doing/using/visiting. Fifthly, by revisiting our findings and our research agenda, we claim that the existing literature does not present so far a comprehensive set of recommendations or best practices for managers. Therefore, managers should use our 
results and findings as an initial list of different scenarios to help them decide when to use VR or gamification, for what purpose and what technology to use.

Due to the nature of this literature review, and its selection and filtering process, this work is not without its limitations. Firstly, it was not possible to perform a meta-analysis due to the large degree of heterogeneity in the studies included in this review. Secondly, it is important to identify the possibility of publication biases, as the search was limited to English and peer-reviewed papers available on a single database, which may limit the number of potential papers identified and included in this review. Nevertheless, none of these limitations detracts from the value of the present research. Indeed, they provide an opportunity to advance research in this domain.

\section{References}

Abbott, L. (1955), Quality and Competition, Columbia University Press, New York, NY.

Agarkar, S.C. (2019), "Influence of learning theories on science education", Resonance, Vol. 24 No. 8, pp. 847-859.

Ajzen, I. (1991), "The theory of planned behavior", Organizational Behavior and Human Decision Processes, Vol. 50 No. 2, pp. 179-211.

Ali, S. (2015), "Key library service dimensions for serving the needs of higher education students in Namibia”, Performance Measurement and Metrics, Emerald Group Publishing Ltd., Vol. 16 No. 3, pp. 263-275.

Alonso, R.R., Plaza, I.R. and Orfali, C.H. (2019), "Barriers in teacher perception about the use of technology for evaluation in higher education", Digital Education Review, No. 35, pp. 170-185.

Alterman, D.M., Jones, T.M., Heidel, R.E., Daley, B.J. and Goldman, M.H. (2011), "The predictive value of general surgery application data for future resident performance", Journal of Surgical Education, Vol. 68 No. 6, pp. 513-518.

Anouncia, M. and Kalyanaraman, P. (2018), "A study on computing and e-learning in the perspective of distributed models", International Journal of Grid and Utility Computing, Inderscience Publishers, Vol. 9 No. 3, p. 243.

Anstadt, S.P., Bradley, S. and Burnette, A. (2013), "Virtual worlds: relationship between real life and experience in second life", International Review of Research in Open and Distributed Learning, Vol. 14 No. 4, pp. 160-190.

Appleton, J.J., Christenson, S.L. and Furlong, M.J. (2008), "Student engagement with school: critical conceptual and methodological issues of the construct", Psychology in the Schools, Vol. 45 No. 5 , pp. 369-386.

Araujo, N., Barroso, B., Gomes, R.A. and Cardoso, L. (2019), "Gamification in the tourism sector: systematic analysis on Scopus database", International Journal of Marketing Communication and New Media, Vol. 7 No. 12, pp. 5-23.

Aron, A., Norman, C.C. and Aron, E.N. (1998), "The self-expansion model and motivation", Representative Research in Social Psychology, Vol. 22, pp. 1-13.

Avellis, G., Agrimi, A., Di Ciano, M., Grasso, G. and Surico, F. (2015a), "e-learning issues in education and training domain of Apulian living labs", Journal of E-Learning and Knowledge Society, Vol. 11 No. 1, pp. 157-164.

Avellis, G., Agrimi, A., Surico, F., Di Ciano, M. and Grasso, G. (2015b), "User's needs in education and training domain of Apulian ICT living labs", International Journal of Education and Information Technologies, Vol. 9, pp. 95-99.

Badenes, A., Mafé, C.R. and Alcañiz, J.E.B. (2019), "Engaging customers through user-and companygenerated content on CSR", Spanish Journal of Marketing-ESIC, Vol. 23 No. 3, pp. 339-371. 
Bandura, A. (1991), "Social cognitive theory of self-regulation", Organizational Behavior and Human Decision Processes, Vol. 50 No. 2, pp. 248-287.

Başal, A. and Kaynak, N.E. (2020), "Perceptions of pre-service English teachers towards the use of digital badges", Innovations in Education and Teaching International, Routledge, Vol. 57 No. 2, pp. 148-162.

Baydas, O. and Cicek, M. (2019), "The examination of the gamification process in undergraduate education: a scale development study", Technology, Pedagogy and Education, Routledge, Vol. 28 No. 3, pp. 269-285.

Bayuk, J. and Altobello, S.A. (2019), "Can gamification improve financial behavior? The moderating role of app expertise”, International Journal of Bank Marketing, Vol. 37 No. 4, pp. 951-975.

Bertram, J., Moskaliuk, J. and Cress, U. (2015), "Virtual training: making reality work?", Computers in Human Behavior, Vol. 43, pp. 284-292.

Bhattacharjee, D., Paul, A., Kim, J.H. and Karthigaikumar, P. (2018), “An immersive learning model using evolutionary learning”, Computers and Electrical Engineering, Vol. 65, pp. 236-249.

Billingsley, G.M. and Scheuermann, B.K. (2014), "Using virtual technology to enhance field experiences for pre-service special education teachers", Teacher Education and Special Education: The Journal of the Teacher Education Division of the Council for Exceptional Children, Vol. 37 No. 3, pp. 255-272.

Bilro, R.G. and Loureiro, S.M.C. (2020), "A consumer engagement systematic review: synthesis and research agenda”, Spanish Journal of Marketing-ESICS, Vol. 24 No. 3, pp. 283-307.

Bilro, R.G., Loureiro, S.M.C. and Guerreiro, J. (2019), "Exploring online customer engagement with hospitality products and its relationship with involvement, emotional states, experience and brand advocacy", Journal of Hospitality Marketing and Management, Vol. 28 No. 2, pp. $147-171$.

Bogacheva, N.V. and Voiskounsky, A.E. (2015), "Virtual worlds of MMORPG: part I. Definition, description, classification", Psychology Journal of the Higher School of Economics, Vol. 12 No. 1, pp. 54-70.

Bouras, C. and Tsiatsos, T. (2006), "Educational virtual environments: design rationale and architecture", Multimedia Tools and Applications, Vol. 29 No. 2, pp. 153-173.

Bower, M., Lee, M.J.W. and Dalgarno, B. (2017), "Collaborative learning across physical and virtual worlds: factors supporting and constraining learners in a blended reality environment", British Journal of Educational Technology, Vol. 48 No. 2, pp. 407-430.

Bragge, J., Kallio, H., Seppälä, T., Lainema, T. and Malo, P. (2017), "Decision-making in a real-time business simulation game: cultural and demographic aspects in small group dynamics", International Journal of Information Technology and Decision Making, Vol. 16 No. 03, pp. 779-815.

Brakus, J.J., Schmitt, B.H. and Zarantonello, L. (2009), "Brand experience: what is it? How is it measured? Does it affect loyalty?", Journal of Marketing, Vol. 73 No. 3, pp. 52-68.

Brandão, A., Pinho, E. and Rodrigues, P. (2019), "Antecedents and consequences of luxury brand engagement in social media”, Spanish Journal of Marketing - ESIC, Vol. 23 No. 2, pp. 163-183.

Brodie, R.J., Hollebeek, L.D., Jurić, B. and Ilić, A. (2011), "Customer engagement: conceptual domain, fundamental propositions, and implications for research", Journal of Service Research, Vol. 14 No. 3, pp. 252-271.

Bum, C.H., Mahoney, T.Q. and Choi, C. (2018), "A comparative analysis of satisfaction and sustainable participation in actual leisure sports and virtual reality leisure sports", Sustainability (Switzerland), MDPI AG, Vol. 10 No. 10, p. 3475.

Çakıroğlu, Ü., Başıbüyük, B., Güler, M., Atabay, M. and YılmazMemiş, B. (2017), "Gamifying an ICT course: influences on engagement and academic performance", Computers in Human Behavior, Elsevier Ltd, Vol. 69, pp. 98-107.
Virtual reality and gamification

203 
Calderón, A., Boubeta-Puig, J. and Ruiz, M. (2018), "MEdit4CEP-Gam: a model-driven approach for user-friendly gamification design, monitoring and code generation in CEP-based systems", Information and Software Technology, Calder, Vol. 95, pp. 238-264.

Callahan, J.L. (2014), "Writing literature reviews: a reprise and update", Human Resource Development Review, Vol. 13 No. 3, pp. 271-275.

Canabal, A. and White, G.O. III (2008), "Entry mode research: past and future", International Business Review, Vol. 17 No. 3, pp. 267-284.

Canals, P.C. and Minguell, M.E. (2018), "GaMoodlification: moodle at the service of the gamification of learning”, Campus Virtuales, Vol. 7 No. 2, pp. 9-25.

Canhoto, A.I. and Murphy, J. (2016), "Learning from simulation design to develop better experiential learning initiatives: an integrative approach", Journal of Marketing Education, Vol. 38 No. 2, pp. 98-106.

Chavarro, D., Ràfols, I. and Tang, P. (2018), "To what extent is inclusion in the web of science an indicator of journal 'quality'?”, Research Evaluation, Vol. 27 No. 2, pp. 106-118.

Chen, Y., Harper, F.M., Konstan, J. and Li, S.X. (2010), "Social comparisons and contributions to online communities: a field experiment on MovieLens", American Economic Review, Vol. 100 No. 4, pp. 1358-1398.

Cheng, Y. and Wang, S.H. (2011), “Applying a 3D virtual learning environment to facilitate student's application ability - the case of marketing", Computers in Human Behavior, Vol. 27 No. 1, pp. 576-584.

Cheong, D. (2010), "The effects of practice teaching sessions in second life on the change in pre-service teachers' teaching efficacy", Computers and Education, Vol. 55 No. 2, pp. 868-880.

Cho, Y.H., Yim, S.Y. and Paik, S. (2015), "Physical and social presence in 3D virtual role-play for preservice teachers", The Internet and Higher Education, Vol. 25, pp. 70-77.

Clarivate (2019), "Web of science - web of science group", available at: https://clarivate.com/ webofsciencegroup/solutions/web-of-science/ (accessed 6 November 2019).

Cooper, G., Park, H., Nasr, Z., Thong, L.P. and Johnson, R. (2019), "Using virtual reality in the classroom: preservice teachers' perceptions of its use as a teaching and learning tool", Educational Media International, Vol. 56 No. 1, pp. 1-13.

Cronin, J.J. and Taylor, S.A. (1994), "SERVPERF versus SERVQUAL: reconciling performance-based and perceptions-minus-expectations measurement of service quality", Journal of Marketing, Vol. 58 No. 1, p. 125.

Csikszentmihalyi, M. (1990), Flow: The Psychology of Optimal Experience, Harper and Row, New York, NY.

Davis, F.D., Bagozzi, R.P. and Warshaw, P.R. (1989), "User acceptance of computer technology: a comparison of two theoretical models", Management Science, Vol. 35 No. 8, pp. 982-1003.

De Guimarães, J.C.F., Severo, E.A., Nóbrega, K.C. and Tondolo, V.A.G. (2019), “Antecedents of student retention: the influence of innovation and quality of teaching in Brazilian universities", International Journal of Innovation and Learning, Inderscience Enterprises Ltd., Vol. 26 No. 3, pp. 235-255.

Deci, E.L. and Ryan, R.M. (2000), “The 'what' and 'why' of goal pursuits: human needs and the selfdetermination of behavior", Psychological Inquiry, Vol. 11 No. 4, pp. 227-268.

Dele-Ajayi, O., Strachan, R., Pickard, A.J. and Sanderson, J.J. (2019), "Games for teaching mathematics in Nigeria: what happens to pupils' engagement and traditional classroom dynamics?", IEEE Access, Institute of Electrical and Electronics Engineers Inc, Vol. 7, pp. 53248-53261.

Dessart, L., Aldás-Manzano, J. and Veloutsou, C. (2019), "Unveiling heterogeneous engagement-based loyalty in brand communities", European Journal of Marketing, Vol. 53 No. 9, pp. 1854-1881. 
Deterding, S., Khaled, R., Nacke, L. and Dixon, D. (2011), “Gamification: toward a definition”, 2011 Annual Conference Extended Abstracts on Human Factors in Computing Systems, ACM, Vancouver, BC, Canada, pp. 12-15.

Dicheva, D., Dichev, C., Agre, G. and Angelova, G. (2015), "Gamification in education: a systematic mapping study", Educational Technology and Society, International Forum of Educational Technology and Society (IFETS), Vol. 18 No. 3, pp. 75-89.

Dirin, A. and Laine, T.H. (2018), "User experience in mobile augmented reality: emotions, challenges, opportunities and best practices”, Computers, Vol. 7 No. 2, pp. 1-18.

Donovan, R.J. and Rossiter, J.R. (1982), "Store atmosphere - an environmental psychology approach", Journal of Retailing, Vol. 58 No. 1, pp. 34-57.

Doumanis, I. and Smith, S. (2015), "A framework for research in gamified mobile guide applications using embodied conversational agents (ECAs)”, International Journal of Serious Games, Vol. 2 No. 3, pp. 21-40.

Durl, J., Trischler, J. and Dietrich, T. (2017), "Co-designing with young consumers - reflections, challenges and benefits", Young Consumers, Vol. 18 No. 4, pp. 439-455.

Dyer, E., Swartzlander, B.J. and Gugliucci, M.R. (2018), "Using virtual reality in medical education to teach empathy", Journal of the Medical Library Association, Vol. 106 No. 4, pp. 498-500.

Economou, D., Mitchell, W.L. and Boyle, T. (2000), "Requirements elicitation for virtual actors in collaborative learning environments", Computers and Education, Vol. 34 Nos 3/4, pp. 225-239.

Englund, C., Olofsson, A.D. and Price, L. (2017), "Teaching with technology in higher education: understanding conceptual change and development in practice", Higher Education Research and Development, Vol. 36 No. 1, pp. 73-87.

Eppmann, R., Bekk, M. and Klein, K. (2018), "Gameful experience in gamification: construction and validation of a gameful experience scale [GAMEX]", Journal of Interactive Marketing, Vol. 43, pp. 98-115.

Fan, W., Wallace, L., Rich, S. and Zhang, Z. (2006), "Tapping the power of text mining", Communications of the ACM, Vol. 49 No. 9, pp. 76-82.

Fernandez, M. (2017), "Augmented-virtual reality: How to improve education systems", Higher Learning Research Communications, Vol. 7 No. 1, p. 1.

Fernandez, C., Esteban, G., Conde, M.A. and Garcia, F. (2016), "Improving motivation in a haptic teaching/learning framework", International Journal of Engineering Education, Vol. 32, pp. 553-562.

Fernández, L.M.S., Rey, E.F. and Murias, R.G. (2019), "The interview as guidance resource in the processes for youth European mobility”, Bordon, Revista de Pedagogia, Sociedad Espanola de Pedagogia, Vol. 71 No. 1, pp. 133-149.

Finn, J.D. and Voelkl, K.E. (1993), "School characteristics related to student engagement", The Journal of Negro Education, Vol. 62 No. 3, pp. 249-268.

Finn, J.D. and Zimmer, K.S. (2012), "Student engagement: what is it? Why does it matter?", in Christenson, S.L., Reschly, A.L. and Wylie, C. (Eds), Handbook of Research on Student Engagement, Springer, New York, NY, pp. 97-131.

Flavián, C., Ibáñez-Sánchez, S. and Orús, C. (2019a), "The impact of virtual, augmented and mixed reality technologies on the customer experience", Journal of Business Research, Vol. 100, pp. 547-560.

Flavián, C., Ibáñez-Sánchez, S. and Orús, C. (2019b), "Integrating virtual reality devices into the body: effects of technological embodiment on customer engagement and behavioral intentions toward the destination", Journal of Travel and Tourism Marketing, Vol. 36 No. 7, pp. 847-863.

Flavián, C., Ibáñez Sánchez, S. and Orús, C. (2020), "Impacts of technological embodiment through virtual reality on potential guests' emotions and engagement", Journal of Hospitality Marketing and Management, available at: https://doi.org/10.1080/19368623.2020.1770146

\section{Virtual reality and gamification}

$\left(\frac{10}{2}\right.$

(1)

, 
Fokides, E. (2017), "Pre-service teachers' intention to use muves as practitioners - a structural equation modeling approach", Journal of Information Technology Education Research, Vol. 16, pp. 47-68.

Fombona, J., Pascual-Sevillano, M.A. and González-Videgaray, M.C. (2017), "m-learning and augmented reality: a review of the scientific literature on the WoS repository", Comunicar, Vol. 25 No. 52, pp. 63-71.

Fredricks, J.A., Blumenfeld, P.C. and Paris, A.H. (2004), "School engagement: potential of the concept, state of the evidence", Review of Educational Research, Vol. 74 No. 1, pp. 59-109.

Gañán, D., Caballé, S., Clarisó, R., Conesa, J. and Bañeres, D. (2017), "ICT-FLAG: a web-based e-assessment platform featuring learning analytics and gamification", International Journal of Web Information Systems, Emerald Group Publishing Ltd., Vol. 13 No. 1, pp. 25-54.

Garcia-Fernandez, J., Fernandez-Gavira, J., Jesus Sanchez-Oliver, A. and Grimaldi-Puyana, M. (2017), "Gamification and mobile applications to entrepreneurship: an educational proposal in higher education", IJERI-International Journal of Educational Research and Innovation, Vol. 8, pp. 248-259.

Garcia Gaitero, O., Costa Roman, O. and Real Garcia, J.J. (2016), “Triangulation of successful sources in teaching: learning styles, gamification and self-regulated learning", Journal of Learning Styles, Vol. 9 No. 18, pp. 117-134.

Garczynski, A.M., Waldrop, J.S., Rupprecht, E.A. and Grawitch, M.J. (2013), "Differentiation between work and nonwork self-aspects as a predictor of presenteeism and engagement: cross-cultural differences", Journal of Occupational Health Psychology, Vol. 18 No. 4, pp. 417-429.

Garrison, D.R., Anderson, T. and Archer, W. (2000), "Critical inquiry in a text-based environment: computer conferencing in higher education", The Internet and Higher Education, Vol. 2 Nos 2/3, pp. 87-105.

Gilal, F.G., Zhang, J., Paul, J. and Gilal, N.G. (2019), "The role of self-determination theory in marketing science: an integrative review and agenda for research", European Management Journal, Vol. 37 No. 1, pp. 29-44.

Goggins, S. and Xing, W. (2016), "Building models explaining student participation behavior in asynchronous online discussion", Computers and Education, Vol. 94, pp. 241-251.

Göksün, D.O. and Gürsoy, G. (2019), "Comparing success and engagement in gamified learning experiences via Kahoot and Quizizz", Computers and Education, Elsevier, Vol. 135 (October 2018), pp. 15-29.

Gopinath Bharathi, A.K.B., Singh, A., Tucker, C.S. and Nembhard, H.B. (2016), "Knowledge discovery of game design features by mining user-generated feedback", Computers in Human Behavior, Elsevier Ltd, Vol. 60, pp. 361-371.

Gupta, S. and Zeithaml, V. (2006), "Customer metrics and their impact on financial performance", Marketing Science, Vol. 25 No. 6, pp. 718-739.

Gustavsson, I., Nilsson, K., Zackrisson, J., Garcia-Zubia, J., Hernandez-Jayo, U., Nafalski, A., Nedic, Z., et al. (2009), "On objectives of instructional laboratories, individual assessment, and use of collaborative remote laboratories", IEEE Transactions on Learning Technologies, Vol. 2 No. 4, pp. 263-274.

Guttentag, D.A. (2010), "Virtual reality: applications and implications for tourism", Tourism Management, Vol. 31 No. 5, pp. 637-651.

Hakak, S., Noor, N.F.M., Ayub, M.N., Affal, H., Hussin, N., Ahmed, E. and Imran, M. (2019), “Cloudassisted gamification for education and learning - recent advances and challenges", Computers and Electrical Engineering, Vol. 74, pp. 22-34.

Harman, K., Koohang, A., Paliszkiewicz, J., Dickinson, P.S., Koohang, A. and Paliszkiewicz, J. (2014), "Scholarly interest in gamification: a citation network analysis", Industrial Management and Data Systems, Vol. 114 No. 9, pp. 1438-1452.

Hartley, M.D., Ludlow, B.L. and Duff, M.C. (2015), "Second life®: a 3D virtual immersive environment for teacher preparation courses in a distance education program", Rural Special Education Quarterly, SAGE Publications, Vol. 34 No. 3, pp. 21-25. 
He, Y., Zhang, Z., Nan, X., Zhang, N., Guo, F., Rosales, E. and Guan, L. (2017), "vConnect: perceive and interact with real world from CAVE", Multimedia Tools and Applications, Vol. 76 No. 1, pp. 1479-1508.

Hirschman, E.C. and Holbrook, M.B. (1982), "Hedonic consumption: emerging concepts, methods and propositions", Journal of Marketing, Vol. 46 No. 3, pp. 92-101.

Hmelo-Silver, C.E. (2004), "Problem-based learning: What and how do students learn?”, Educational Psychology Review, Vol. 16 No. 3, pp. 235-266.

Hofacker, C.F., de Ruyter, K., Lurie, N.H., Manchanda, P. and Donaldson, J. (2016), “Gamification and

Virtual reality and gamification

Hoffmann, H., Oertli, D., Mechera, R., Dell-Kuster, S., Rosenthal, R., Reznick, R. and MacDonald, H. (2017), "Comparison of Canadian and Swiss surgical training curricula: moving on toward competency-based surgical education”, Journal of Surgical Education, Vol. 74 No. 1, pp. 37-46.

Hollebeek, L.D., Glynn, M.S. and Brodie, R.J. (2014), "Consumer Brand engagement in social media: conceptualisation, scale development and validation", Journal of Interactive Marketing, Vol. 28 No. 2, pp. 149-165.

Holobar, A., Divjak, M., Prelog, I., Korošec, D. and Zazula, D. (2008), "A distributed virtual reality-based system for neonatal decision-making training", Computer Applications in Engineering Education, Vol. 15 No. 4, pp. 329-339.

Howard, J.A. and Jagdish, S. (1969), The Theory of Buyer Behavior, John Wiley and Sons, New York, NY.

Huang, L.-T. (2017), "Exploring consumers' intention to urge to buy in mobile commerce: the perspective of pleasure-arousal-dominance", Twenty First Pacific Asia Conference on Information Systems, pp. 1-13.

Huang, T.-C., Shu, Y., Yeh, T.-C. and Zeng, P.-Y. (2016), "Get lost in the library? An innovative application of augmented reality and indoor positioning technologies", The Electronic Library, Vol. 34 No. 1, pp. 2-34.

Huggins, R. and Thompson, P. (2015), "Entrepreneurship, innovation and regional growth: a network theory", Small Business Economics, Vol. 45 No. 1, pp. 103-128.

Huotari, K. and Hamari, J. (2012), "Defining gamification - a service marketing perspective", Proceedings of The 16th International Academic Mindtrek Conference, ACM Press, Tampere, Finland, pp. 17-22.

Illeris, K. (2009), Contemporary Theories of Learning, Contemporary Theories of Learning, 2nd ed., Routledge, available at: https://doi.org/10.4324/9780203870426

Jalani, N.H. and Sern, L.C. (2015), "Efficiency comparisons between example-problem-based learning and teacher-centered learning in the teaching of circuit theory", Procedia-Social and Behavioral Sciences, Vol. 204, pp. 153-163.

Janssen, D., Tummel, C., Richert, A. and Isenhardt, I. (2016), "Virtual environments in higher education - immersion as a key construct for learning 4.0", International Journal of Advanced Corporate Learning (IJAC), Vol. 9 No. 2, pp. 20-26.

Jimerson, S.R., Campos, E. and Greif, J.L. (2003), "Toward an understanding of definitions and measures of school engagement and related terms", The California School Psychologist, Vol. 8 No. 1, pp. 7-27.

Jung, T.H. and Tom Dieck, M.C. (2017), "Augmented reality, virtual reality and 3D printing for the cocreation of value for the visitor experience at cultural heritage places", Journal of Place Management and Development, Emerald Group Publishing Ltd., Vol. 10 No. 2, pp. 140-151.

Jurado, F. and Echeverria Meza, R. (2017), "An exploratory study in the use of gamer profiles and learning styles to build educational videogames", International Journal of Engineering Education, Vol. 33 No. 2, B, SI, pp. 797-806.

Kahiya, E.T. (2018), "Five decades of research on export barriers: review and future directions", International Business Review, Vol. 27 No. 6, pp. 1172-1188. 
Kalyani, D. and Rajasekaran, K. (2018), "Innovative teaching and learning", Journal of Applied and Advanced Research, Vol. 3 No. S1, p. 23.

Kapp, K.M. (2012), The Gamification of Learning and Instruction, John Wiley and Sons Inc., San Francisco.

Katsionis, G. and Virvou, M. (2008), "Personalised e-learning through an educational virtual reality game using web services", Multimedia Tools and Applications, Vol. 39 No. 1, pp. 47-71.

Kaur, N. and Geetha, G. (2015), "Play and learn DS: interactive and gameful learning of data structure", International Journal of Technology Enhanced Learning, Vol. 7 No. 1, pp. 44-56.

Ketyi, A. (2016), "From mobile language learning to gamification: an overlook of research results with business management students over a five-year period", Porta Linguarum, No. SI, pp. 45-60.

Kim, S. (2014), "Decision support model for introduction of gamification solution using AHP", The Scientific World Journal, Vol. 2014.

Kim, K. and Ahn, S.(G.). (2017), "The role of gamification in enhancing intrinsic motivation to use a loyalty program", Journal of Interactive Marketing, Vol. 40 No. 1, pp. 41-51.

Kim, H.J. and Kim, B.H. (2018), "Implementation of young children English education system by AR type based on P2P network service model", Peer-to-Peer Networking and Applications, Vol. 11 No. 6, pp. 1252-1264.

Kim, M.J., Lee, C.K. and Jung, T. (2018), "Exploring consumer behavior in virtual reality tourism using an extended stimulus-organism-response model”, Joumal of Travel Research, Vol. 59 No. 1, pp. 1-21.

Kim, C., Park, S.W., Cozart, J. and Lee, H. (2015), "From motivation to engagement: the role of effort regulation of virtual high school students in mathematics courses", Educational Technology and Society, Vol. 18 No. 4, SI, pp. 261-272.

Kim, H., Shin, H., Kim, H.S. and Kim, W.T. (2018), "VR-CPES: a novel cyber-physical education systems for interactive VR services based on a mobile platform”, Mobile Information Systems, Vol. 2018.

Kim, C.M., Kim, M.K., Lee, C.J., Spector, J.M. and DeMeester, K. (2013), “Teacher beliefs and technology integration", Teaching and Teacher Education, Vol. 29 No. 1, pp. 76-85.

Knoll, J. and Matthes, J. (2017), "The effectiveness of celebrity endorsements: a meta-analysis”, Journal of the Academy of Marketing Science, Vol. 45 No. 1, pp. 55-75.

Koivisto, J. and Hamari, J. (2014), "Demographic differences in perceived benefits from gamification", Computers in Human Behavior, Vol. 35, pp. 179-188.

Kumar, V. and Pansari, A. (2016), “Competitive advantage through engagement”, Journal of Marketing Research, Vol. 53 No. 4, pp. 497-514.

Lamb, L.C., DiFiori, M.M., Jayaraman, V., Shames, B.D. and Feeney, J.M. (2017), “Gamified twitter microblogging to support resident preparation for the American board of surgery in-service training examination", Journal of Surgical Education, Vol. 74 No. 6, pp. 986-991.

Lasry, N., Charles, E. and Whittaker, C. (2014), "When teacher-centered instructors are assigned to student-centered classrooms", Physical Review Special Topics - Physics Education Research, American Physical Society, Vol. 10, p. 010116.

Leclercq, T., Hammedi, W. and Poncin, I. (2018), "The boundaries of gamification for engaging customers: effects of losing a contest in online co-creation communities", Journal of Interactive Marketing, Vol. 44, pp. 82-101.

Leventhal, H., Nerenz, D. and Steele, D. (1984), "Illness representations and coping with health threats", in Baum, A. and Singer, J. (Eds.), A Handbook of Psychology and Health, Vol. 4, Lawrence Erlbaum, pp. 219-252.

Lin, Y.L. and Yang, J.C. (2016), “Augmented reality based learning applied to green energy”, Journal of Materials Education, Vol. 38 Nos 1/2, pp. 37-50.

Looyestyn, J., Kernot, J., Boshoff, K., Ryan, J., Edney, S. and Maher, C. (2017), "Does gamification increase engagement with online programs? A systematic review”, Plos One, Vol. 12 No. 3, p. e0173403. 
Lopez Carrillo, D., Calonge Garcia, A., Rodriguez Laguna, T., Ros Magan, G., Lebron Moreno, J.A., Carrillo, D.L., García, A.C., et al. (2019), "Using gamification in a teaching innovation project at the university of Alcalá: a new approach to experimental science practices", The Electronic Journal of E-Learning, Academic Publishing Ltd., Vol. 17 No. 2, pp. 93-106.

Loureiro, S.M.C., Bilro, R.G. and Japutra, A. (2019a), "The effect of consumer-generated media stimuli on emotions and consumer brand engagement", Journal of Product and Brand Management, Vol. 29 No. 3, pp. 387-408.

Loureiro, S.M.C., Guerreiro, J. and Ali, F. (2020), "20 years of research on virtual reality and augmented

Virtual reality and gamification reality in tourism context: a text-mining approach", Tourism Management, Vol. 77, available at: https://doi.org/10.1016/j.tourman.2019.104028

Loureiro, S.M.C., Miranda, F.J. and Breazeale, M. (2014), "Who needs delight? The greater impact of value, trust and satisfaction in utilitarian, frequent-use retail", Journal of Service Management, Vol. 25 No. 1, pp. 101-124.

Loureiro, S.M.C., Romero, J. and Bilro, R.G. (2019b), "Stakeholder engagement in co-creation processes for innovation: a systematic literature review and case study", Journal of Business Research, Vol. 119 (October), pp. 388-409.

Loureiro, S.M.C., Guerreiro, J., Eloy, S., Langaro, D. and Panchapakesan, P. (2019c), "Understanding the use of virtual reality in marketing: a text mining-based review", Journal of Business Research, Vol. 100, pp. 514-530.

Ludlow, B.L. (2015), "Virtual reality: emerging applications and future directions", Rural Special Education Quarterly, Vol. 34 No. 3, pp. 3-10.

Ma, Z. (2019), "Effects of immersive stories on prosocial attitudes and willingness to help: testing psychological mechanisms", Media Psychology, Routledge, Vol. in Press, pp. 1-26.

Macfadyen, L.P. and Dawson, S. (2012), "Numbers are not enough. Why e-learning analytics failed to inform an institutional strategic plan Leah", Educational Technology and Society, Vol. 15 No. 3, pp. 149-163.

Macfarlane, B. and Tomlinson, M. (2017), "Critiques of student engagement”, higher education policy”, Higher Education Policy, Vol. 30 No. 1, pp. 5-21.

Macpherson, A. and Holt, R. (2007), "Knowledge, learning and small firm growth: a systematic review of the evidence", Research Policy, Vol. 36 No. 2, pp. 172-192.

Maheu, M.M., Pulier, M.L., McMenamin, J.P. and Posen, L. (2012), "Future of telepsychology, telehealth, and various technologies in psychological research and practice", Professional Psychology: Research and Practice, Vol. 43 No. 6, pp. 613-621.

Marcelo, C., Yot, C. and Mayor, C. (2015), "University teaching with digital technologies", Comunicar, Vol. 23 No. 45, pp. 117-124.

Martí-Parreño, J., Méndez-Ibáñez, E. and Alonso-Arroyo, A. (2016), "The use of gamification in education: a bibliometric and text mining analysis", Journal of Computer Assisted Learning, Vol. 32 No. 6, pp. 663-676.

Martín-Del-Pozo, M., Muñoz-Repiso, A.G.V. and Martín, A.H. (2019), "Video games and collaborative learning in education? A scale for measuring in-service teachers' attitudes towards collaborative learning with video games", Informatics, Vol. 6 No. 3, pp. 1-13.

Mavroeidi, A.G., Kitsiou, A., Kalloniatis, C. and Gritzalis, S. (2019), "Gamification vs privacy: identifying and analysing the major concerns", Future Internet, Vol. 11 No. 3, p. 67.

Mehrabian, A. and Russell, J.A. (1974), An Approach to Environmental Psychology, An Approach to Environmental Psychology, MIT Press, Cambrige, MA.

Mikropoulos, T.A., Katsikis, A., Nikolou, E. and Tsakalis, P. (2003), "Virtual environments in biology teaching", Journal of Biological Education, Vol. 37 No. 4, pp. 176-181.

Milligan, G.W. and Cooper, M.C. (1985), "An examination of procedures for determining the number of clusters in a data set”, Psychometrika, Vol. 50 No. 2, pp. 159-179. 
Mollen, A. and Wilson, H. (2010), "Engagement, telepresence and interactivity in online consumer experience: reconciling scholastic and managerial perspectives", Journal of Business Research, Vol. 63 Nos 9/10, pp. 919-925.

Monferrer, D., Moliner, M.A. and Estrada, M. (2019), "Increasing customer loyalty through customer engagement in the retail banking industry", Spanish Journal of Marketing -ESIC, Vol. 23 No. 3, pp. 461-484.

Morimoto, S.A. and Friedland, L.A. (2013), "Cultivating success: youth achievement, capital and civic engagement in the contemporary United States", Sociological Perspectives, Vol. 56 No. 4, pp. 523-546.

Muñoz-Cristóbal, J.A., Jorrín-Abellan, I.M., Asensio-Peréz, J.I., Martínez-Monés, A., Prieto, L.P. and Dimitriadis, Y. (2015), "Supporting teacher orchestration in ubiquitous learning environments: a study in primary education", IEEE Transactions on Learning Technologies, Institute of Electrical and Electronics Engineers, Vol. 8 No. 1, pp. 83-97.

Muñoz-Cristóbal, J.A., Gallego-Lema, V., Arribas-Cubero, H.F., Martínez-Monés, A. and Asensio-Pérez, J.I. (2017), "Using virtual learning environments in bricolage mode for orchestrating learning situations across physical and virtual spaces", Computers and Education, Elsevier Ltd, Vol. 109, pp. 233-252.

Mulvey, M.S., Lever, M.W. and Elliot, S. (2019), "A cross-national comparison of intra-generational variability in social media sharing", Journal of Travel Research, Vol. 59 No. 7, pp. 1-17.

Navarro, A.M., Climent, V.C. and Palacio, J.R.S. (2017), "La educación de postgrado en economía social en la universidad española ¿una asignatura pendiente?”, CIRIEC-Espana Revista de Economia Publica, Social y Cooperativa, CIRIEC, Vol. 89 No. 1, pp. 33-54.

Nilson, L.B. (2010), Teaching at Its Best - A Research-Based Resource for College Instructors, 3rd ed., Jossey-Bass.

Nousiainen, T., Kangas, M., Rikala, J. and Vesisenaho, M. (2018), "Teacher competencies in game-based pedagogy", Teaching and Teacher Education, Vol. 74, pp. 85-97.

Nurul, S. and Mohamad, M. (2018), "Gamification approach in education to increase learning engagement", International Journal of Humanities, Arts and Social Sciences, Vol. 4 No. 1, pp. 22-32.

O'Connor, E.A. and Domingo, J. (2017), "A practical guide, with theoretical underpinnings, for creating effective virtual reality learning environments", Journal of Educational Technology Systems, Vol. 45 No. 3, pp. 343-364.

O'Flaherty, J. and Phillips, C. (2015), "The use of flipped classrooms in higher education: a scoping review", The Internet and Higher Education, Elsevier Ltd, Vol. 25, pp. 85-95.

Oleksy, T. and Wnuk, A. (2017), "Catch them all and increase your place attachment! The role of location-based augmented reality games in changing people - place relations", Computers in Human Behavior, Vol. 76, pp. 3-8.

Oliver, R.L. (1980), "A cognitive model of the antecedents and consequences of satisfaction decisions", Journal of Marketing Research, Vol. 17 No. 4, p. 460.

Oliver, R.L., Rust, R.T. and Varki, S. (1997), "Customer delight: foundations, findings, and managerial insight”, Journal of Retailing, Vol. 73 No. 3, pp. 311-336.

Orús, C., Gurrea, R. and Ibáñez-Sánchez, S. (2019), "The impact of consumers' positive online recommendations on the omnichannel webrooming experience", Spanish Journal of Marketing ESIC, Vol. 23 No. 3, pp. 397-413.

Packman, A. and Meredith, G. (2011), "Technology and the evolution of clinical methods for stuttering”, Journal of Fluency Disorders, Vol. 36 No. 2, pp. 75-85.

Pansari, A. and Kumar, V. (2017), "Customer engagement: the construct, antecedents, and consequences", Journal of the Academy of Marketing Science, Vol. 45 No. 3, pp. 294-311.

Pappa, D. and Papadopoulos, H. (2019), "A use case of the application of advanced gaming and immersion technologies for professional training: the GAMEPHARM training environment for physiotherapists", Electronic Journal of E-Learning, Vol. 17 No. 2, pp. 157-170. 
Parasuraman, A., Zeithaml, V.A. and Berry, L.L. (1988), "Servqual: a multiple-item scale for measuring consumer PERC", Journal of Retailing, Vol. 64, pp. 12-40.

Parkinson, B. and Hudson, P. (2002), "Extending the learning experience using the web and a knowledge-based virtual environment", Computers and Education, Vol. 38 Nos 1/3, pp. 95-102.

Paul, J. and Benito, G.R. (2018), "A review of research on outward foreign direct investment from emerging countries, including China: what do we know, how do we know and where should we be heading?", Asia Pacific Business Review, Vol. 24 No. 1, pp. 90-115.

Paul, J. and Mas, E. (2019), “Toward a 7-P framework for international marketing”, Journal of Strategic Marketing, pp. 1-21.

Paul, J. and Rosado-Serrano, A. (2019), "Gradual internationalisation vs born-global/international new venture models: a review and research agenda”, International Marketing Review, Vol. 36 No. 6, pp. 830-858.

Paul, J., Parthasarathy, S. and Gupta, P. (2017), "Exporting challenges of SMEs: a review and future research agenda", Journal of World Business, Vol. 52 No. 3, pp. 327-342.

Pechenkina, E. (2017), "Developing a typology of mobile apps in higher education: a national casestudy", Australasian Journal of Educational Technology, Vol. 33 No. 4, pp. 134-146.

Petit, O., Velasco, C. and Spence, C. (2019), "Digital sensory marketing: integrating new technologies into multisensory online experience", Journal of Interactive Marketing, Vol. 45, pp. $42-61$.

Pickering, C.E.Z., Ridenour, K., Salaysay, Z., Reyes-Gastelum, D. and Pierce, S.J. (2018), "EATI island a virtual-reality-based elder abuse and neglect educational intervention”, Gerontology and Geriatrics Education, Vol. 39 No. 4, pp. 445-463.

Pine, B.J. and Gilmore, J.H. (1998), "Welcome to the experience economy", Harvard Business Review, Vol. 76 No. 4, pp. 97-105.

Piñeiro-Otero, T. and Costa-Sánchez, C. (2015), "ARG (alternate reality games). contributions, limitations, and potentialities to the service of the teaching at the university level", Comunicar, Grupo Comunicar Ediciones, Vol. 22 No. 44, pp. 141-148.

Pittaway, L., Robertson, M., Munir, K., Denyer, D. and Neely, A. (2004), "Networking and innovation: a systematic review of the evidence", International Journal of Management Reviews, Vol. 5-6 Nos 3/4, pp. 137-168.

Portman, M.E., Natapov, A. and Fisher-Gewirtzman, D. (2015), "To go where no man has gone before: virtual reality in architecture, landscape architecture and environmental planning", Computers, Environment and Urban Systems, Vol. 54, pp. 376-384.

Pritchard, A. (2009), Ways of Learning - Learning Theories and Learning Styles in the Classroom, Routledge, London.

Punj, G. and Stewart, D.W. (1983), "Cluster analysis in marketing research: review and suggestions for application”, Journal of Marketing Research, Vol. 20 No. 2, pp. 134-148.

Putman, S.M., Ford, K. and Tancock, S. (2012), "Redefining online discussions: using participant stances to promote collaboration and cognitive engagement", International Journal of Teaching and Learning in Higher Education, Vol. 24 No. 2, pp. 151-167.

Ramaswamy, V. and Ozcan, K. (2018), "What is co-creation? An interactional creation framework and its implications for value creation", Journal of Business Research, Vol. 84, pp. 196-205.

Ramos, C. and Yudko, E. (2008), "Hits' (not 'discussion posts') predict student success in online courses: a double cross-validation study", Computers and Education, Vol. 50 No. 4, pp. 1174-1182.

Randhawa, K., Wilden, R. and Hohberger, J. (2016), “A bibliometric review of open innovation: setting a research agenda”, Journal of Product Innovation Management, Vol. 33 No. 6, pp. 750-772.
Virtual reality and gamification 
SJME

25,2

Rather, R.A., Tehseen, S. and Parrey, S.H. (2018), "Promoting customer brand engagement and brand loyalty through customer brand identification and value congruity", Spanish Journal of Marketing-ESIC, Vol. 22 No. 3, pp. 319-337.

Riva, G. (2000), "From telehealth to E-health: internet and distributed virtual reality in health care", Cyberpsychology and Behavior, Vol. 3 No. 6, pp. 989-998.

Robson, K. (2019), "Motivating professional student behavior through a gamified personal branding assignment", Journal of Marketing Education, Vol. 41 No. 2, pp. 154-164.

Rodrigues, L.F., Oliveira, A. and Rodrigues, H. (2019), "Main gamification concepts: a systematic mapping study", Heliyon, Vol. 5 No. 7, p. e01993.

Roschk, H., Loureiro, S.M.C. and Breitsohl, J. (2017), "Calibrating 30 years of experimental research: a meta-analysis of the atmospheric effects of music, scent, and color", Journal of Retailing, Vol. 93 No. 2, pp. 228-240.

Ryan, R.M. and Deci, E.L. (2000a), "Self-determination theory and the facilitation of intrinsic motivation, social development, and well-being", American Psychologist, Vol. 55 No. 1, pp. 68-78.

Ryan, R.M. and Deci, E.L. (2000b), "Intrinsic and extrinsic motivations: classic definitions and new directions", Contemporary Educational Psychology, Vol. 25 No. 1, pp. 54-67.

Saxena, L. (2006), "E-learning resource management knowledge", in Pan, Z.G., Diener, H., Jin, X.G., Gobel, S. and Li, L. (Eds), Technologies for E-Learning and Digital Entertainment Proceedings, Vol. 3942, pp. 140-146.

Schunk, D.H. (2012), Learning Theories an Educational Perspective, 6th ed., Pearson, Boston, MA.

Schwade, F. and Schubert, P. (2018), "The ERP challenge: developing an integrated platform and course concept for teaching ERP skills in universities", International Journal of Human Capital and Information Technology Professionals, Vol. 9 No. 1, pp. 53-69.

Sesen, B.A. and Tarhan, L. (2011), "Active-learning versus teacher-centered instruction for learning acids and bases", Research in Science and Technological Education, Vol. 29 No. 2, pp. 205-226.

Séraphin, H., Butcher, J. and Korstanje, M. (2017), "Challenging the negative images of Haiti at a previsit stage using visual online learning materials", Journal of Policy Research in Tourism, Leisure and Events, Routledge, Vol. 9 No. 2, pp. 169-181.

Shams, S.M.R. and Kaufmann, H.R. (2016), "Entrepreneurial co-creation: a research vision to be materialised”, Management Decision, Vol. 54 No. 6, pp. 1250-1268.

Sherman, E., Mathur, A. and Smith, R.B. (1997), "Store environment and consumer purchase behavior: mediating role of consumer emotions", Psychology and Marketing, Vol. 14 No. 4, pp. 361-378.

Sheth, J.N. and Parvatiyar, A. (1995), "Relationship marketing in consumer markets: antecedents and consequences”, Journal of the Academy of Marketing Science, Vol. 23 No. 4, pp. 255-270.

Shuhuai, R., Xingjun, S., Haiqing, L. and Jialin, C. (2009), "From information commons to knowledge commons: building a collaborative knowledge sharing environment for innovative communities", The Electronic Library, Vol. 27 No. 2, pp. 247-257.

Sicilia, M. and Palazón, M. (2008), "Brand communities on the internet: a case study of Coca-Cola's Spanish virtual community, corporate communications", Corporate Communications: An International Journal, Vol. 13 No. 3, pp. 255-270.

Siemens, J.C., Smith, S., Fisher, D., Thyroff, A. and Killian, G. (2015), "Level up! The role of progress feedback type for encouraging intrinsic motivation and positive brand attitudes in public versus private gaming contexts", Journal of Interactive Marketing, Vol. 32, pp. 1-12.

Silva, P.V.T., da Budel, G.C. and Ross, P.R. (2018), "A formação continuada em atendimento educacional especializado: uma experiência no ambiente virtual de aprendizagem eureca", revista Ibero-Americana de estudos Em educação", Revista Ibero-Americana de Estudos em Educação, Vol. 13 No. 2, pp. 855-871. 
Silva, R., Rodrigues, R. and Leal, C. (2019), "Play it again: how game-based learning improves flow in accounting and marketing education”, Accounting Education, Vol. 28 No. 5, pp. 484-507.

Sinclair, J. and Aho, A.M. (2017), "Virtual learning environments: adoption without progression", International Journal of Learning Technology, Vol. 12 No. 4, pp. 326-347.

Skinner, E.A., Kindermann, T.A., Connell, J.P. and Wellborn, J.G. (2009), Engagement and Disaffection as Organisational Constructs in the Dynamics of Motivational Development, edited by Wenzel, K.R. and Wigfield, A., Routledge, New York, NY.

Spinakis, A. and Chatzimakri, A. (2005), "Comparative study of text mining tools", in Sirmakessis S. (Ed.), Knowledge Mining. Studies in Fuzziness and Soft Computing, Vol. 185, Springer, Berlin, Heidelberg, pp. 223-232.

Srivastava, A.N. and Sahami, M. (2009), “Text mining: classification”, Clustering, and Applications, Chapman and Hall/CRC, New York, NY, USA.

Su, C.H. (2017), "Designing and developing a novel hybrid adaptive learning path recommendation system (ALPRS) for gamification mathematics geometry course”, Eurasia Journal of Mathematics Science and Technology Education, Vol. 13 No. 6, pp. 2275-2298.

Subhash, S. and Cudney, E.A. (2018), "Gamified learning in higher education: a systematic review of the literature”, Computers in Human Behavior, Vol. 87 No. 5, pp. 192-206.

Suh, A. and Prophet, J. (2018), "The state of immersive technology research: a literature analysis", Computers in Human Behavior, Vol. 86, pp. 77-90.

Sun, C., Hu, W. and Xu, D. (2019), "Navigation modes, operation methods, observation scales and background options in UI design for high learning performance in VR-based architectural applications",Journal of Computational Design and Engineering, Vol. 6 No. 2, pp. 189-196.

Takács, B. (2011), "Immersive interactive reality: internet-based on-demand VR for cultural presentation”, Virtual Reality, Vol. 15 No. 4, pp. 267-278.

Tawfik, M., Sancristobal, E., Martin, S., Gil, R., Diaz, G., Colmenar, A., Peire, J., et al. (2013), "Virtual instrument systems in reality (VISIR) for remote wiring and measurement of electronic circuits on breadboard”, IEEE Transactions on Learning Technologies, Vol. 6 No. 1, pp. 60-72.

Tecau, A.S., Bratucu, G., Tescaşiu, B., Chiţ u, I.B., Constantin, C.P. and Foris, D. (2019), "Responsible tourism-integrating families with disabled children in tourist destinations”, Sustainability, Vol. 11 No. 16, pp. 1-18.

Terjesen, S., Hessels, J. and Li, D. (2013), “Comparative international entrepreneurship: a review and research agenda”, Journal of Management, Vol. 42 No. 1, pp. 1-46.

Thrush, E.A. and Bodary, M. (2000), "Virtual reality, combat, and communication", Journal of Business and Technical Communication, SAGE Publications Inc., Vol. 14 No. 3, pp. 315-327.

Tian, K., Sautter, P., Fisher, D., Fischbach, S., Luna-Nevarez, C., Boberg, K., Kroger, J., et al. (2014), "Transforming health care: empowering therapeutic communities through technology-enhanced narratives", Journal of Consumer Research, Vol. 41 No. 2, pp. 237-260.

Torres-Toukoumidis, A., Romero-Rodríguez, L.M., Pérez-Rodríguez, M.A. and Björk, S. (2018), "Modelo teórico integrado de gamificación en ambientes e-learning (E-MIGA), revista complutense de educación”, Revista Complutense de Educación, Vol. 29 No. 1, pp. 129-145.

Tranfield, D., Denyer, D. and Smart, P. (2003), "Towards a methodology for developing evidenceinformed management knowledge by means of systematic review", British Journal of Management, Vol. 14 No. 3, pp. 207-222.

Venkatesh, V., Thong, J.Y.L. and Xu, X. (2012), "Consumer acceptance and use of information technology: extending the unified theory of acceptance and use of technology", MIS Quarterly, Vol. 36 No. 1, pp. 157-178.

Venkatesh, V., Morris, M.G., Davis, G.B. and Davis, F.D. (2003), "User acceptance of information technology: toward a unified view”, Mis Quarterly, Vol. 27 No. 3, pp. 425-478.
Virtual reality and gamification

213 
Veselovsky, M.Y., Pogodina, T.V., Ilyukhina, R.V., Sigunova, T.A. and Kuzovleva, N.F. (2018), "Financial and economic mechanisms of promoting innovative activity in the context of the digital economy formation”, Entrepreneurship and Sustainability Issues, Vol. 5 No. 3, pp. 672-681.

Vouk, M.A., Bitzer, D.L. and Klevans, R.L. (1999), "Workflow and end-user quality of service issues in web-based education", IEEE Transactions on Knowledge and Data Engineering, Vol. 11 No. 4, pp. 673-687.

Warren, C., Batra, R., Loureiro, S.M.C. and Bagozzi, R.P. (2019), "Brand coolness", Journal of Marketing, Vol. 83 No. 5, pp. 38-56.

Westbrook, R.A. and Oliver, R.L. (1991), "The dimensionality of consumption emotion patterns and consumer satisfaction", Journal of Consumer Research, Vol. 18 No. 1, p. 84.

Wu, Y., Chen, S.C. and Lin, I.C. (2019), "Elucidating the impact of critical determinants on purchase decision in virtual reality products by analytic hierarchy process approach", Virtual Reality, Springer, London, Vol. 23 No. 2, pp. 187-195.

Xie, K. and Ke, F. (2011), "The role of students' motivation in peer-moderated asynchronous online discussions", British Journal of Educational Technology, Vol. 42 No. 6, pp. 916-930.

Xie, K., Debacker, T.K. and Ferguson, C. (2006), "Extending the traditional classroom through online discussion: the role of student motivation", Journal of Educational Computing Research, Vol. 34 No. 1, pp. 67-89.

$\mathrm{Xu}, \mathrm{F}$., Buhalis, D. and Weber, J. (2017), "Serious games and the gamification of tourism”, Tourism Management, Vol. 60, pp. 244-256.

Yim, M.Y.C., Chu, S.C. and Sauer, P.L. (2017), "Is augmented reality technology an effective tool for Ecommerce? An interactivity and vividness perspective", Journal of Interactive Marketing, Vol. 39, pp. 89-103.

Yoon, S.Y., Choi, Y.J. and Oh, H. (2015), "User attributes in processing 3D VR-enabled showroom: gender, visual cognitive styles, and the sense of presence", International Journal of HumanComputer Studies, Vol. 82, pp. 1-10.

Zhu, E. (2006), "Interaction and cognitive engagement: an analysis of four asynchronous online discussions", Instructional Science, Vol. 34 No. 6, pp. 451-480.

Zichermann, G. and Cunningham, C. (2011), Gamification by Design, O’Reilly, Canada.

\section{Corresponding author}

Sandra Maria Correia Loureiro can be contacted at: sandramloureiro@netcabo.pt 
